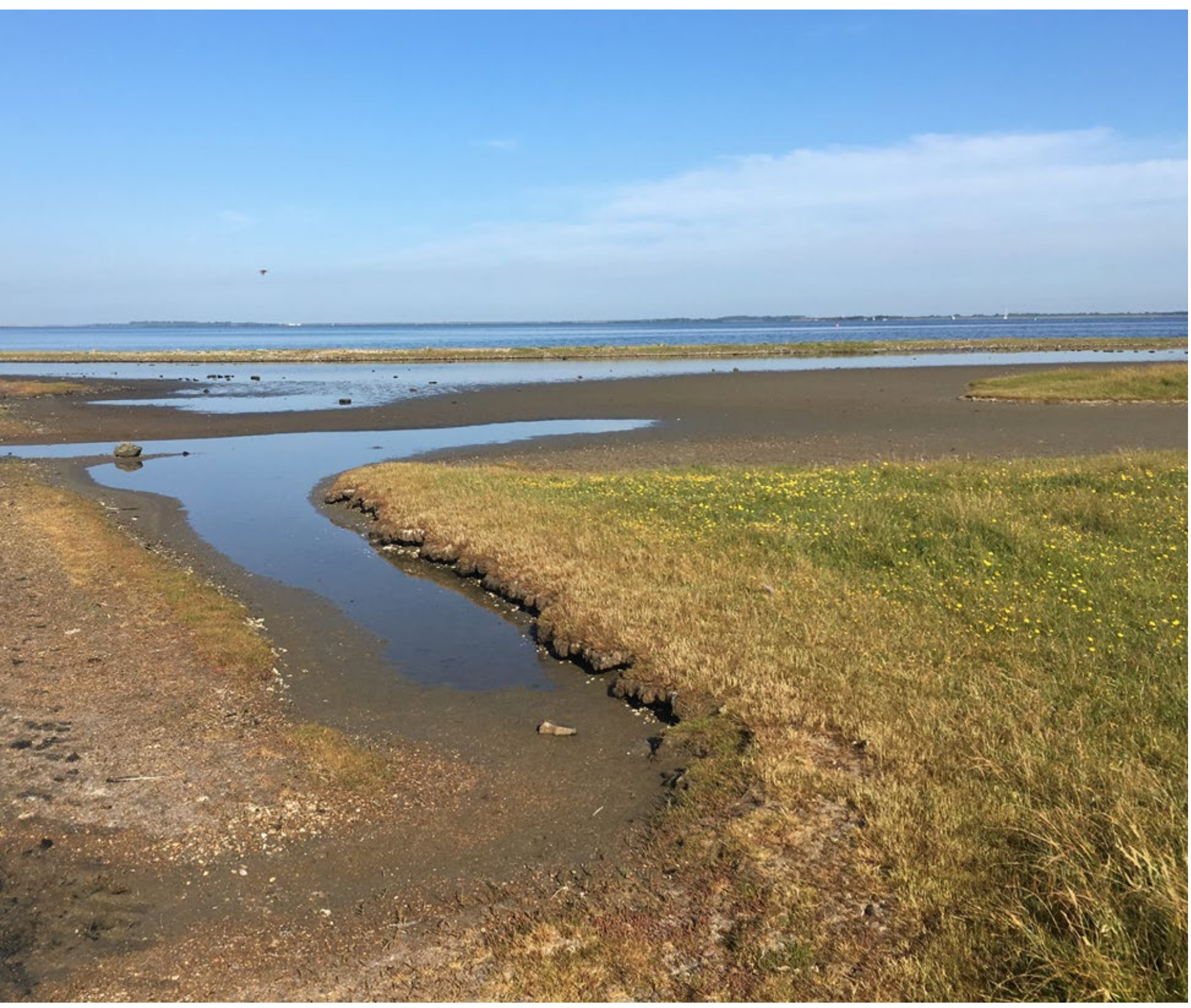

\title{
Een quickscan naar ecologische draagkracht voor filter feeders nu en bij gedempt getij
}




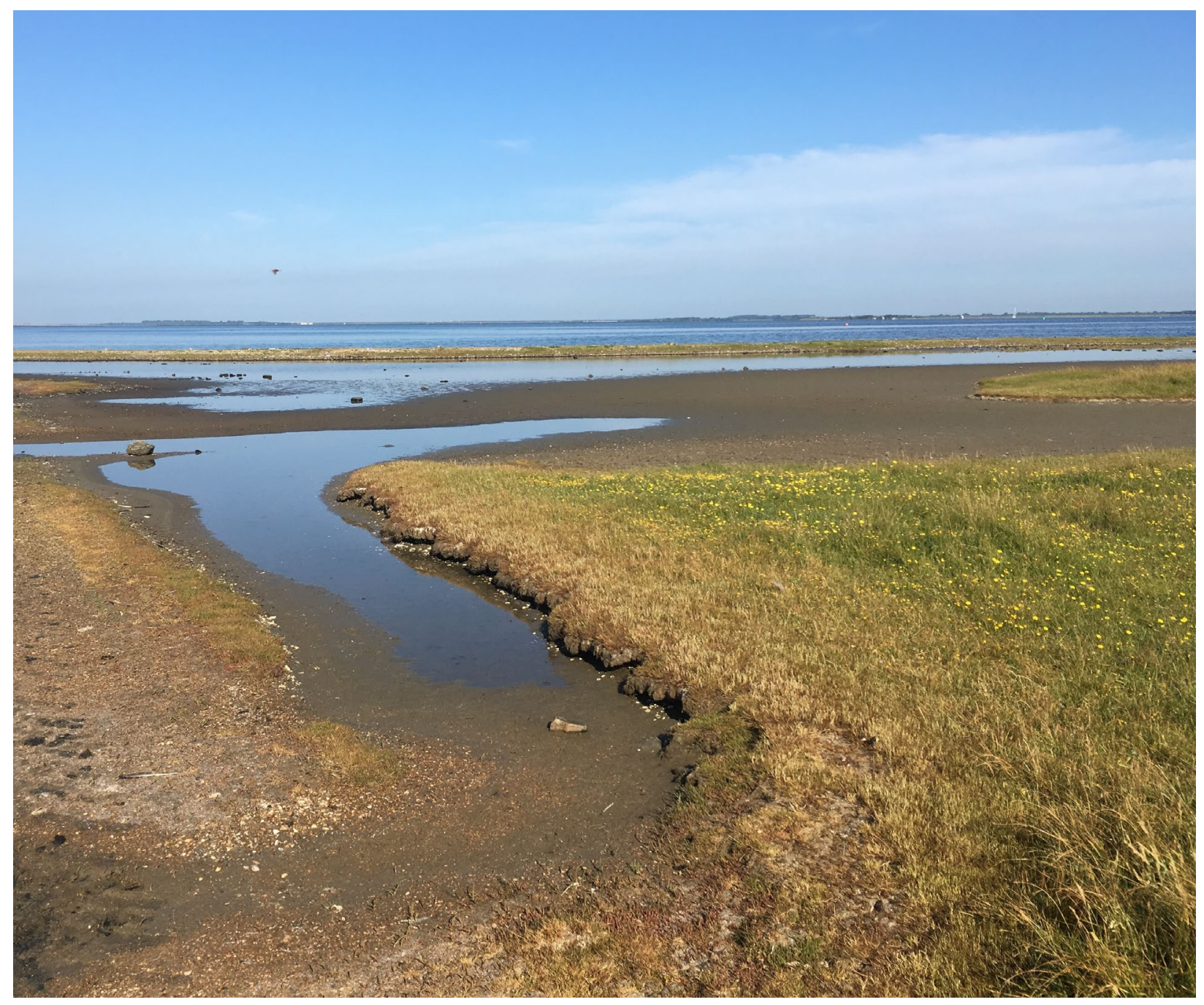

\section{Een quickscan naar ecologische draagkracht voor filter feeders nu en bij gedempt getij}


Keywords: draagkracht, natuurwaarden, schelpdieren, Grevelingenmeer

Opdrachtgever: Staatsbosbeheer

T.a.v.: Sandra den Adel-Aartsen

Haven van Bommenede 1

4316 PC Zonnemaire

Dit rapport is gratis te downloaden van https://doi.org/10.18174/540260

Wageningen Marine Research verstrekt geen gedrukte exemplaren van rapporten.

h

Wageningen Marine Research is ISO 9001:2015 gecertificeerd.

Foto omslag: Ingeborg Mulder

(c) Wageningen Marine Research

Wageningen Marine Research, instituut binnen de rechtspersoon Stichting

Wageningen Research, hierbij

vertegenwoordigd door

Dr. ir. J.T. Dijkman, Managing director

KvK nr. 09098104,

WMR BTW nr. NL 8113.83.696.B16.

Code BIC/SWIFT address: RABONL2U

IBAN code: NL 73 RABO 0373599285
Wageningen Marine Research aanvaardt geen aansprakelijkheid voor gevolgschade, noch voor schade welke voortvloeit uit toepassingen van de resultaten van werkzaamheden of andere gegevens verkregen van Wageningen Marine Research. Opdrachtgever vrijwaart Wageningen Marine Research van aanspraken van derden in verband met deze toepassing.

Alle rechten voorbehouden. Niets uit deze uitgave mag weergegeven en/of gepubliceerd worden, gefotokopieerd of op enige andere manier gebruikt worden zonder schriftelijke toestemming van de uitgever of auteur. 


\section{Inhoud}

$\begin{array}{lr}\text { Samenvatting } & 4\end{array}$

$1 \quad$ Inleiding $\quad 6$

$1.1 \quad$ Achtergrond \& aanleiding $\quad 6$

$\begin{array}{lll}1.2 & \text { Doelstelling } & 7\end{array}$

$\begin{array}{lll}1.3 \text { Aanpak } & 8\end{array}$

1.4 Leeswijzer $\quad 8$

2 Beschrijving van waterbeheer, natuurwaarden, schelpdierkweek en scenario met gedempt getij 10

$\begin{array}{lll}2.1 & \text { Waterbeheer } & 10\end{array}$

$\begin{array}{ll}2.2 \text { Natuurwaarden } & 11\end{array}$

$\begin{array}{ll}2.3 \text { Schelpdierkweek } & 11\end{array}$

$\begin{array}{ll}2.4 & \text { Scenario met gedempt getij } \\ \end{array}$

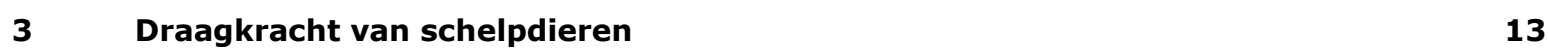

$\begin{array}{lll}3.1 & \text { Wat is draagkracht } & 13\end{array}$

3.2 Indicatoren voor draagkracht $\quad 14$

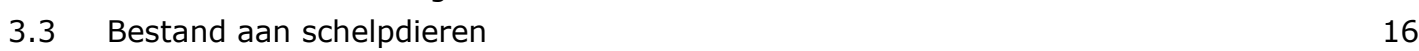

3.3.1 Kweekbestanden in het huidige Grevelingenmeer $\quad 16$

3.3.2 Huidige natuurlijke schelpdierbestanden in het Grevelingenmeer 19

3.3.3 Gevolgen van introductie gedempt getij voor schelpdierkweek 21

$\begin{array}{lll}\text { 3.3.4 Draagkracht voor schelpdieren } & 22\end{array}$

3.3.5 Ruimte voor extra graasdruk in scenario met gedempt getij 23

$4 \quad$ Conclusie en discussie $\quad 24$

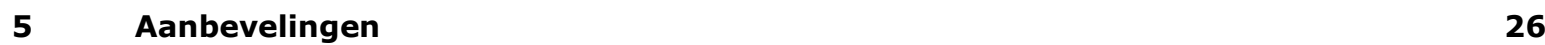

$\begin{array}{llr}6 & \text { Kwaliteitsborging } & 28\end{array}$

$\begin{array}{lr}\text { Literatuur } & 29\end{array}$

$\begin{array}{lr}\text { Verantwoording } & 32\end{array}$ 


\section{Samenvatting}

Het Grevelingenmeer is ontstaan na afdamming in de jaren '70 en vormt nu het grootste zout water meer van Europa. Medio 2018 is het project Getij Grevelingen gestart waarin de aanleg van een doorlaatmiddel in de Brouwersdam wordt voorbereid. Dit doorlaatmiddel moet leiden tot een verbetering van de waterkwaliteit en ecologie in het Grevelingenmeer met een gedempt getij van 40 $\mathrm{cm}$. Staatsbosbeheer vindt het daarom van belang om te zoeken naar een duurzame balans tussen voedsel voor alle gekweekte- en wilde schelpdieren en overige grazers in een situatie met gedempt getij. Het doel van deze studie is om meer inzicht te krijgen in de huidige ecologische draagkracht van het Grevelingenmeer voor schelpdieren en bepalen hoe dit verandert in een situatie met gedempt getij.

De draagkracht van het Grevelingenmeer is het resultaat van de interactie tussen de externe aanvoer van algen (vanuit de Noordzee), de primaire productie en de filtratiedruk van de grazers. De groep van grazers bestaat uit allerlei verschillende organismen zoals schelpdieren, zoöplankton en vissen waarvoor algen hun voedsel vormen. Veel van de Natura 2000 doelsoorten zijn direct of indirect afhankelijk van dit voedselweb, maar bevinden zich nu in een slechte staat van instandhouding, in het bijzonder de (trek)vogels.

Draagkracht is een complex begrip en wordt beïnvloed door verschillende factoren die variëren in ruimte en tijd. In deze studie is een inventarisatie gemaakt van de huidige draagkracht van het Grevelingenmeer gebaseerd op vrij grove indicatoren. Vervolgens is gekeken naar de groeimogelijkheden binnen een scenario met gedempt getij. Deze waardes moeten gezien worden als een indicatie of trend, maar kunnen door de aannames die gedaan moeten worden niet gezien worden als absolute waardes. Om de draagkracht te kunnen bepalen zijn de volgende stappen genomen: i) bepalen van het huidige schelpdierbestand en bijbehorende graasdruk, ii) bepalen van de voedselbeschikbaarheid. Aan de hand van deze gegevens, tezamen met verversingstijd, kunnen de indicatoren worden berekend.

In de huidige situatie lijkt de maximale schelpdierbestandsgrootte bereikt, wat erop wijst dat de grenzen voor grazers in het systeem en/of duurzame exploitatie van schelpdieren bereikt zijn. De vraag is of een situatie met gedempt getij meer mogelijkheden biedt om natuurlijke bestanden en mogelijk ook schelpdierkweek, te laten toenemen. Momenteel zijn schelpdieren afhankelijk van voedsel dat door primaire productie in het Grevelingenmeer zelf wordt geproduceerd (interne productie). De import van algen vanuit de Noordzee is gering (externe import). In een situatie met gedempt getij neemt de uitwisseling met de Noordzee weliswaar toe (4-5x snellere verversing), toch zal ook in deze nieuwe situatie de interne productie nog steeds het belangrijkste zijn voor de voedselbeschikbaarheid van schelpdieren. In deze studie is het Grevelingenmeer als één systeem benaderd. Wel is het mogelijk dat er ruimtelijke verschillen zijn; namelijk dat de schelpdierkweek nabij de Brouwersdam wel mogelijk kan profiteren van algen die vanuit de Noordzee aangevoerd worden. Meer landinwaarts zal de interne productie van groot belang zijn. Dergelijke ruimtelijke verschillen kunnen alleen met gedetailleerde modellen onderzocht worden.

Naast verhoogde uitwisseling is het ook de verwachting dat de primaire productie (groei van algen) met een factor $1.5 \mathrm{zal}$ toenemen in een situatie met gedempt getij. Dit leidt volgens de berekeningen in deze studie tot een hogere draagkracht van het systeem voor grazers zoals schelpdieren. De totale graasdruk kan met ruim $10 \%$ toenemen ten opzichte van de huidige situatie zonder effect te hebben op de relatieve graasdruk (Grazing Ratio, GR) van het systeem. Deze extra beschikbare graasdruk kan door verschillende soorten schelpdieren maar ook door zoöplankton, vissen, zakpijpen, sponzen of andere filter feeders worden ingevuld. Vertaald naar schelpdieren komt deze toename in graasdruk bijvoorbeeld overeen met 12 miljoen kg Japanse oesters, 21 miljoen kg platte oesters, 4 miljoen $\mathrm{kg}$ mosselen of 8 miljoen kg kokkels. 
Met de beschikbare data hebben we een inventarisatie kunnen maken van de draagkracht in de huidige situatie en in een situatie met gedempt getij. De evaluatie van draagkracht kan echter worden geoptimaliseerd, dit is van belang gezien de vragen die zich afspelen rondom de introductie van gedempt getij in het Grevelingenmeer. Ook op het vlak van empirische metingen zijn verbeteringen mogelijk, zoals frequentere bestandsschattingen, betere schattingen van bestandsgrootte en graasdruk van mesheften en strandgapers, meenemen schelpdiergegevens hard substraat en inzetten op onafhankelijke metingen vleesgehalte mosselen. Ook kunnen analyse technieken aangescherpt worden door de ruimtelijke en temporele variatie binnen een systeem beter mee te nemen in de berekeningen van de draagkracht indices. 


\section{$1 \quad$ Inleiding}

Staatsbosbeheer is beheerder van de terrestrische buitendijkse natuur in de Grevelingen doorlopend tot $1,70 \mathrm{~m}$ - NAP waterdiepte. Als natuur- landschap- en recreatiebeheerder is zij goed bekend met de terrestrische natuur in het gebied. Ontwikkeling van kennis over de onderwaternatuur en de samenhang met de bovenwaternatuur vindt Staatsbosbeheer belangrijk om haar rol goed in te kunnen vullen. Zeker gezien de ambitie van de organisatie om deze natuur te beschermen, te laten beleven en te benutten. Staatsbosbeheer streeft naar een duurzame balans in het natuurlijk ecosysteem en het gebruik ervan.

Medio 2018 is het project Getij Grevelingen gestart dat wordt getrokken door Rijkswaterstaat, Staatsbosbeheer, Ministeries I\&W, LNV en EZK, provincies Zeeland en Zuid-Holland en de gemeenten Schouwen-Duivenland en Goeree-Overflakkee en waarin de aanleg van een doorlaatmiddel in de Brouwersdam wordt voorbereid. Dit doorlaatmiddel moet leiden tot een verbetering van de waterkwaliteit en ecologie in het Grevelingenmeer met een gedempt getij van $40 \mathrm{~cm}$ en een middenpeil van NAP $-0,30 \mathrm{~cm}$. De verwachting is dat met gedempt getij de primaire productie (groei van microalgen) zal toenemen en dat er daardoor meer voedsel beschikbaar komt voor organismen die van microalgen leven: 'de grazers'. Een belangrijke groep onder de grazers zijn de schelpdieren. De verwachting is dat schelpdieren kunnen profiteren van de verhoogde primaire productie en de verbeterde wateruitwisseling met de Noordzee. Hiermee nemen ook de kansen voor duurzame schelpdierkweek in het Grevelingenmeer toe.

\subsection{Achtergrond \& aanleiding}

Het Grevelingenmeer als grootste zoutwatermeer van Europa en met schrale soortenrijke vegetaties en broedgebied voor kustbroedvogels langs de randen vormt een bijzonder natuurgebied en vertegenwoordigt waardevolle natuurwaarden. De oevers en eilanden van het Grevelingenmeer zijn dan ook beschermd als onderdeel van Natura-2000. Daarnaast vormt het meer een belangrijk foerageergebied voor vele soorten watervogels en komen er ook zeehonden voor die beschermd zijn onder Natura 2000. Ook valt het Grevelingenmeer onder de Kaderrichtlijn Water. Tegelijkertijd vormt het Grevelingenmeer een populair recreatiegebied en vindt er naast visserij ook kweek van schelpdieren plaats.

De verwachting is dat door introductie van gedempt getij de primaire productie zal toenemen waar de grazers (en in het bijzonder de filterfeeders) van kunnen profiteren door meer beschikbaarheid van microalgen en dus voedsel. Deze groep bestaat uit schelpdieren en andere filtrerende bodemdieren zoals zakpijpen, sponzen, (koker)wormen, het zoöplankton (dit is een diverse groep met als belangrijkste diergroepen kreeftachtigen, maar ook larven van diverse diersoorten en ook de kwallen en ribkwallen behoren tot deze groep) en tot slot de planktivore vissen. De grazers vormen een diverse groep en belangrijke schakel in het voedselweb tussen microalgen en de hogere trofische niveau's (Figuur 1). 


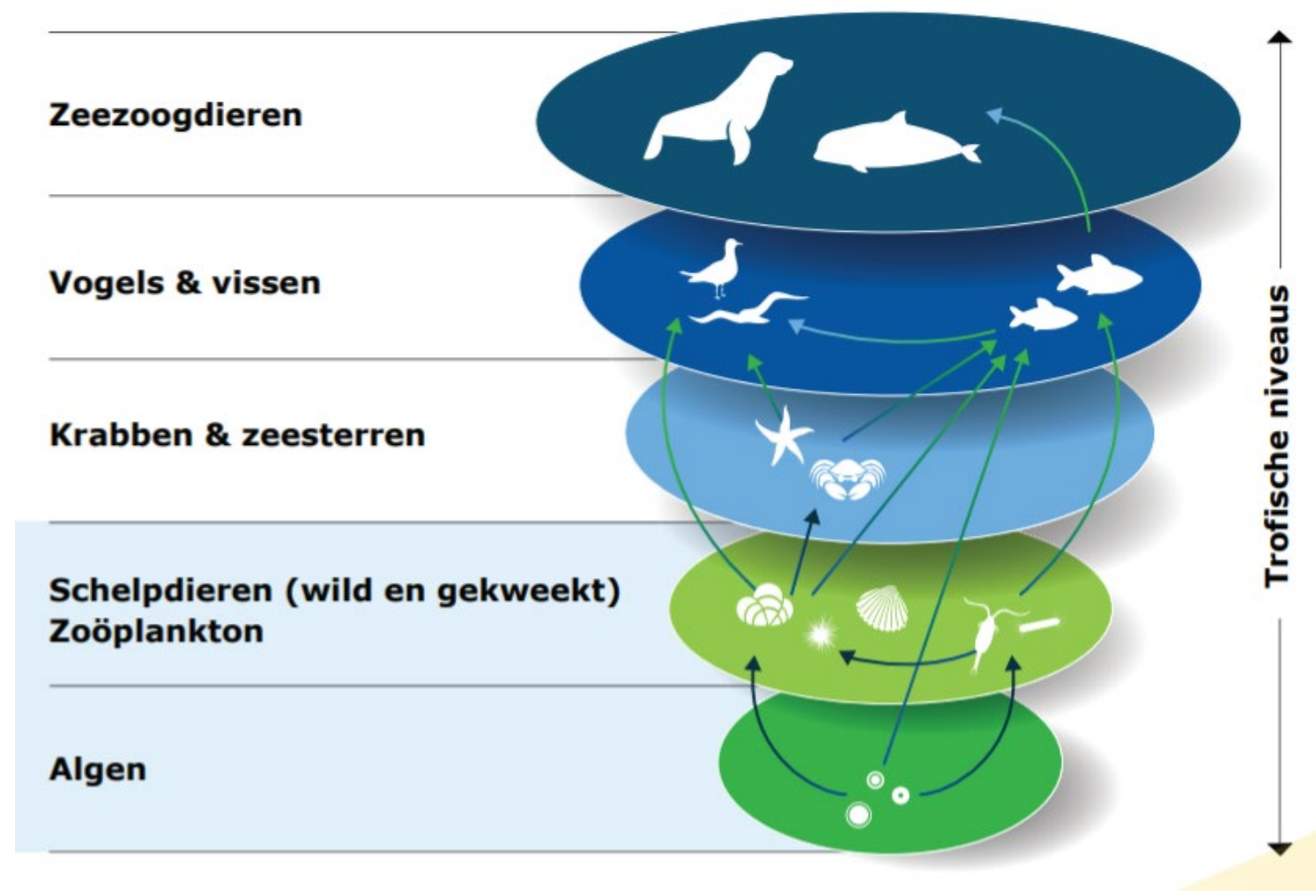

Figuur 1. Microalgen zijn de basis van het voedselweb, en worden gegeten door de 'grazers' die met elkaar concurreren bestaande uit schelpdieren (zowel wilde als gekweekte) en andere bodemdieren zoals zakpijpen, sponzen, (koker)wormen en het zoöplankton. Deze groep vormt een belangrijke schakel tussen microalgen en de hogere trofische niveau's in het voedselweb (gebaseerd op: Wijsman \& Jansen, 2019).

Veel van de Natura 2000 doelsoorten, in het bijzonder de (trek)vogels, zijn direct of indirect afhankelijk van dit voedselweb, maar bevinden zich nu in een slechte staat van instandhouding. Staatsbosbeheer wil meer inzicht krijgen in de gevolgen van gedempt getij voor de ecologische draagkracht voor grazers als belangrijke schakel in het voedselweb ten opzichte van de huidige situatie. Vanwege databeschikbaarheid wordt gefocust op de belangrijkste grazers in het systeem, de schelpdieren. Van zoöplankton en filterfeeders op de harde substraten zoals zakpijpen en sponzen is voor het Grevelingenmeer weinig bekend. Met inzicht in de ecologische draagkracht voor schelpdieren kan de gebruiksruimte voor natuur en mogelijke extra kweek van schelpdieren worden ingeschat. Hierbij gaat het om de hoeveelheid schelpdieren (of andere grazers) die er extra bij kunnen komen zonder negatieve effecten te hebben op het ecosysteem functioneren. Dit kunnen natuurlijke en/of gekweekte soorten zijn.

\subsection{Doelstelling}

Het doel van dit rapport is om meer inzicht te krijgen in de huidige ecologische draagkracht van het Grevelingenmeer voor schelpdieren en bepalen hoe dit verandert in een situatie met gedempt getij.

Hierbij is de draagkracht van het Grevelingenmeer bepaald volgens de definities die zijn gegeven in Smaal \& van Duren (2019). In dit rapport zijn hiertoe de volgende stappen ondernomen:

1. Het toelichten van het concept draagkracht.

2. Het berekenen van de draagkracht in het Grevelingenmeer in de huidige situatie en in een situatie met gedempt getij. 


\subsection{Aanpak}

Draagkracht, de balans tussen de beschikbaarheid van algen en de filtratiedruk door schelpdieren, is complex omdat verschillende factoren invloed kunnen hebben op deze verhouding. De infographic in Figuur 2 geeft een vereenvoudigde weergave van door welke factoren draagkracht wordt bepaalt. In de huidige studie hebben we eenzelfde aanpak gekozen als eerder voor de Oosterschelde (Jansen et al 2019) en het Grevelingenmeer (Smaal \& Wijsman 2014). Deze aanpak (methodiek) is in meerdere studies toegepast zoals Smaal et al. (2013), Smaal \& Wijsman (2014), Smaal (2017), Wijsman \& Smaal (2017), Jansen et al. (2019), Kamermans \& Van Asch (2019), Smaal \& van Duren (2019), Wijsman (2019) en is gebaseerd op Dame en Prins (1998). De tekst omtrent draagkracht in de onderstaande hoofdstukken is gebaseerd op de bovengenoemde literatuur en er zullen daarom geen referentie verwijzingen meer worden gegeven in de tekst.

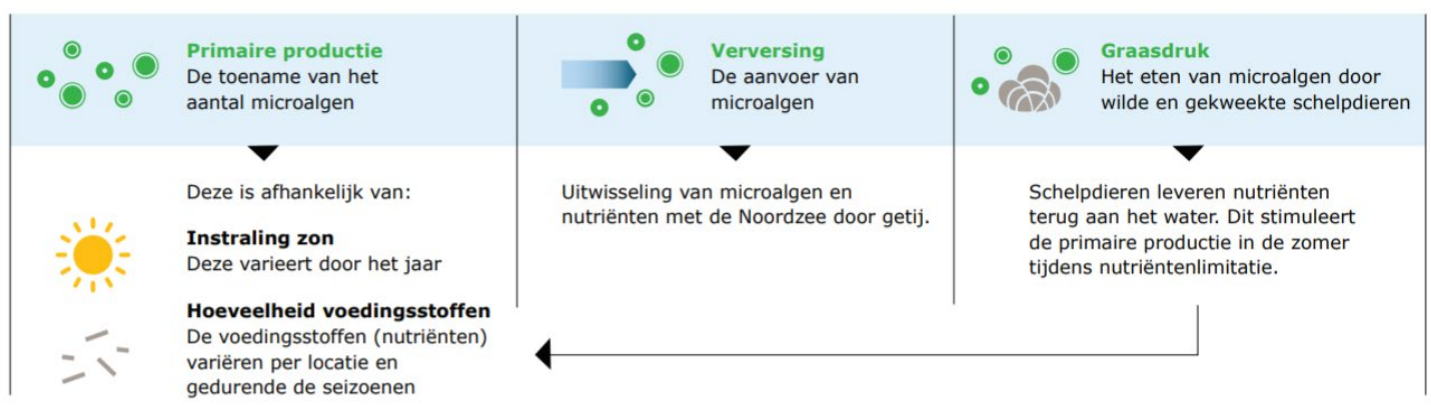

Figuur 2. Infographic: Draagkracht beschrijft de hoeveelheid schelpdieren die in een ecosysteem geproduceerd kan worden, zonder dat deze een negatief effect hebben op de beschikbare hoeveelheid voedsel (microalgen). Draagkracht is afhankelijk van primaire productie, verversing en graasdruk (gebaseerd op: Wijsman \& Jansen, 2019).

Om de draagkracht te kunnen bepalen zijn de volgende stappen genomen:

- $\quad$ Het bepalen van schelpdierbestanden en de bijbehorende graasdruk.

- Het bepalen van voedsel beschikbaarheid

- Het berekenen van draagkracht indices: Clearance Ratio (CR) en Grazing Ratio (GR) geven een indicatie van de verhouding tussen graasdruk en voedselbeschikbaarheid. Deze waarden kunnen gebruikt worden om grote veranderingen in een systeem aan te duiden of een vinger aan de pols te houden. Deze indices worden vaak gebruikt om gebieden met elkaar te vergelijken. In dit geval zullen we ze gebruiken om de huidige situatie te vergelijken met een situatie waarin gedempt tij wordt toegepast.

Deze analyse-stappen worden in de volgende hoofdstukken nader toegelicht. Vervolgens is gekeken hoeveel schelpdieren een scenario met gedempt getij kunnen ondersteunen zonder dat er sprake zou zijn van overbegrazing van het systeem.

\subsection{Leeswijzer}

Allereerst wordt er in hoofdstuk 2 een beschrijving gegeven van de ontwikkelingen in het waterbeheer van het moment voor de afsluiting van de Grevelingen tot heden. Vervolgens wordt er kort ingegaan op de huidige natuurwaarden, schelpdierkweek en wordt er aan de hand van modellen (Maarse et al. 2019) besproken welke veranderingen (o.a. voedselaanbod, verversing, zuurstofarm areaal) worden verwacht op te treden in een situatie met gedempt getij.

Hoofdstuk 3 is gericht op bepaling van draagkracht. Eerst wordt uitgelegd wat draagkracht is en worden parameters besproken welke van belang zijn om de draagkracht te kunnen bepalen zoals primaire productie, graasdruk en verblijftijden. Daarna wordt de huidige draagkracht van het Grevelingenmeer berekend. Ten slot wordt berekend hoeveel het schelpdierbestand mogelijk kan toenemen in een situatie met gedempt getij wanneer er wordt uitgaan van eenzelfde interactie tussen voedsel en graasdruk als in de huidige situatie. 
In hoofdstuk 4 en 5 worden de belangrijkste conclusies en aanbevelingen vermeld welke zijn gemaakt op basis van deze studie. 


\section{Beschrijving van waterbeheer, natuurwaarden, schelpdierkweek en scenario met gedempt getij}

\subsection{Waterbeheer}

Tot 1964 was de Grevelingen een estuarium met uitgestrekte slikken, platen en schorren. Zout Noordzeewater kwam binnen via de monding en via de oostelijke verbinding met de Oosterschelde; zoetwater van de Rijn en Maas werd aangevoerd via het Krammer-Volkerak. Het zoutgehalte was meer dan $10 \mathrm{~g} \mathrm{Cl}^{-} \mathrm{I}^{-1}$ en het getijverschil gemiddeld $2.3 \mathrm{~m}$. In die tijd werd het gebied gebruikt voor de mossel- en oesterkweek (Smaal en Wijsman 2014). In 1964 is de Grevelingen afgesloten van de zoetwaterafvoer van de grote rivieren door de aanleg van de Grevelingendam en veranderde de Grevelingen van een estuarium in een zeearm. Er kwam alleen nog zoutwater via de monding binnen, waardoor de zoet-zout gradiënt verdween en er een open zeearm met getij ontstond. Het zoutgehalte varieerde tussen 14 en $17 \mathrm{~g} \mathrm{Cl}^{-} \mathrm{I}^{-1}$.

In 1971 is de Grevelingen afgesloten van de Noordzee door de aanleg van de Brouwersdam. Door deze afsluiting is het grootste zoutwatermeer van West Europa ontstaan, het Grevelingenmeer, waar invloed van het getij is verdwenen en de waterbeweging en de menging voornamelijk wordt beïnvloed door wind. Door een neerslagoverschot en lozing van relatief zoet polderwater werd het Grevelingenmeer na 1971 steeds zoeter. De vissers van het Grevelingenmeer verkeerden aanvankelijk in de veronderstelling dat het meer een zoet binnenmeer zou gaan worden waar geen plaats meer zou zijn voor mossel- of oesterteelt. Uitwijken naar de Oosterschelde leek ook geen mogelijkheid omdat ook dat water op de nominatie stond om volledig afgesloten te worden van zee. De vissers stonden daarmee voor de keus om of de kweek volledig naar de Waddenzee te verplaatsen of over te schakelen op de palingvisserij. Dat laatste deden 12 visserijbedrijven uit Bruinisse, Tholen en Ouddorp. De mosselkwekers onder hen moesten hun mosselpercelen daarvoor inleveren (VBC Grevelingenmeer 2010).

De verzoeting had een slechte invloed op de waterkwaliteit van het meer. Daarom is er besloten om spui- en verversingssluizen te bouwen in de dammen. In de Brouwersdam zijn sluiskokers gebouwd die in 1978 zijn voltooid en in de Grevelingendam is in 1983 een hevel aangelegd (Bannink et al. 1984, Visser 1995). De hevel is oorspronkelijk aangelegd om de chloridegehalten in het Zijpe en de Krabbenkreek in de Oosterschelde bij de sluiting van de Philipsdam in 1986 op een aanvaardbaar niveau te houden. Omdat de verversing door de sluiskokers in de Brouwersdam voldoende waren is de hevel alleen gebruikt voor een aantal proeven. De hevel, ofwel de Flakkeese spuisluis, is sinds 1987 buiten gebruik totdat deze in 2017 opnieuw is geopend om een tweezijdig debiet mogelijk te maken en meer verversing in het oostelijk deel van het Grevelingenmeer te creëren ten bate van de waterkwaliteit. Echter in 2018 is de spuisluis weer gesloten en tijdelijk niet functioneel ten behoeve van de bouw van een testcentrum voor turbines.

De aanleg van de spuisluis in de Brouwersdam leidde er toe dat oesterbroed zich kon afzetten op de tijdens de afsluiting afgestorven mosselbanken. Een ontwikkeling die niemand had kunnen voorzien toen in 1964 de Grevelingendam werd aangelegd. Deze platte oesters waren een gewild product. Met instemming van het ministerie van LNV werden een aantal proefvakken uitgezet om de oesterteelt weer te beginnen. De oesterteelt bleek een succes (VBC Grevelingenmeer 2010).

De spuisluis in de Brouwersdam staat in principe jaarrond open voor doorspoeling met Noordzeewater uit de Voordelta (W\&B 2012). Met deze spuisluis wordt ook het waterpeil van -0.2 m NAP in het Grevelingenmeer geregeld. Om dit te bereiken moet de sluis ongeveer $8 \%$ van de tijd gesloten zijn. Met het water door de spuisluis wordt ook het zoutgehalte in het Grevelingenmeer in stand gehouden 
en kan de stratificatie en zuurstofloosheid in de diepte putten in het Grevelingenmeer worden beperkt (Wetsteijn 2011).

Om de schieraal tijdens hun trek vast te houden in het Grevelingenmeer werd de spuisluis aanvankelijk 30 dagen gesloten in het najaar zodat de beroepsvissers optimaal op de wegtrekkende schieraal konden vissen. Sinds 2006 is deze regeling opgeheven en is de spuisluis jaarrond open (VBC Grevelingenmeer 2010).

\subsection{Natuurwaarden}

$\mathrm{Na}$ de afsluiting zijn de natuurwaarden van het Grevelingenmeer sterk veranderd, zowel in het open water als op de drooggevallen, voormalige slikken en platen. Het meer vormt daarmee een relatief jong ecosysteem dat nog steeds in verandering is na de afsluiting.

De natuurwaarden in het Grevelingenmeer zijn in vele rapportages beschreven (zie bijvoorbeeld MER rapportages: Dienst Landelijk gebied, 2014a, Dienst Landelijk gebied 2014b) en wordt hier daarom alleen op hoofdlijnen besproken. Volgens het Natura 2000 Beheerplan Grevelingen 2016-2022 (Ministerie van Infrastructuur \& Milieu 2016) zijn de belangrijkste ecologische waarden van het Natura 2000 gebied Grevelingenmeer:

- $\quad$ Als het grootste zoutwatermeer van Europa vormt het Grevelingenmeer een belangrijk leefgebied voor kustbroedvogels, moerasbroedvogels van rietruigtes, (doortrekkende en overwinterende) watervogels en roofvogels. Met name kustbroedvogels (kluut, bontbekplevier, strandplevier, visdief, grote stern en dwergstern) zijn belangrijk en het Grevelingenmeer vormt een onmisbare schakel in het trekvogelnetwerk. Vooral voor visetende watervogels is het Grevelingenmeer van uitzonderlijk belang waaronder fuut, middelste zaagbek, geoorde fuut, kuifduiker, dodaars, lepelaar en kleine zilverreiger.

- Diversiteit aan vegetatietypen: zoutminnende pioniervegetaties, zilte graslanden, riet- en zoutvegetatie vochtige duinvalleien, ontzilte graslandvegetaties, duinvegetaties, struwelen en ruigtes. Verschillende zeldzame en beschermde plantensoorten komen in deze vegetaties voor, waaronder de groenknolorchis.

- Het Grevelingenmeer is een belangrijk leefgebied voor de noordse woelmuis.

Het beheerplan duidt ook een aantal knelpunten aan voor het Grevelingenmeer waaronder het probleem van de waterkwaliteit (zuurstofloosheid). Door de beperkte dynamiek van het water treedt tijdens de zomer temperatuurstratificatie op in het Grevelingenmeer waardoor er zuurstofdepletie kan optreden in de onderste waterlaag. Dit is een belangrijk zorgpunt voor de ecologie omdat dit proces kan leiden tot afsterven van bodemleven en daarmee ook verdere gevolgen heeft voor het systeem (bv. verminderd voedsel voor vissen en vogels). Zie ook de uitgevoerde systeem analyse door Tangelder et al. (2019).

\subsection{Schelpdierkweek}

Het Grevelingenmeer is geschikt voor schelpdierkweek vanwege de beschutte ligging en geringe temperatuurverschillen, maar heeft een beperkte uitwisseling met de Noordzee waardoor de voedseltoevoer vanuit de Noordzee beperkt is. Momenteel vindt er commerciële schelpdierkweek plaats van de Japanse en platte oester op een gebied van ca. 550 ha. Daarnaast wordt er geëxperimenteerd met mosselzaadvanginstallaties (MZI's) en hangcultuurmosselen (MHC) nabij de Brouwersdam. Op dit moment vertegenwoordigt de hoeveelheid gekweekte schelpdieren ca. 3.4\% (kweekbestand) van alle schelpdieren bij elkaar in het Grevelingenmeer. In de Oosterschelde is dit percentage meer dan 50\%: het aandeel kweekmosselen in de periode 1992 tot 2014 bedroeg 19-55\% van het totale schelpdierbestand en het aandeel kweekoesters maakte $<10 \%$ uit van het gehele bestand schelpdieren (Jansen et al. 2019). De kweek van schelpdieren in het Grevelingenmeer is dus beperkt ten opzichte van de kweek in de Oosterschelde. 
Vanuit beleid, beheer en vanuit ondernemers worden vragen gesteld met betrekking tot draagkracht (letterlijk hoeveel schelpdieren kan het systeem dragen) voor schelpdieren. Niet alleen omdat er bij gedempt getij meer voedsel beschikbaar komt voor schelpdieren, maar ook omdat de gekweekte schelpdieren concurreren om het beschikbare voedsel met de van nature aanwezige schelpdieren en andere van algen afhankelijke soorten. De totale hoeveelheid voedsel die beschikbaar is voor de schelpdieren is afhankelijk van diverse processen zoals primaire productie, import van algen, kwaliteit van de algen, filtratiesnelheid (graasdruk), waterbeweging, etc. (Dame en Prins 1998, Smaal et al. 2013, Smaal \& Wijsman 2014, Smaal 2017, Wijsman \& Smaal 2017, Jansen et al. 2019, Kamermans \& Van Asch 2019, Smaal \& van Duren 2019, Wijsman 2019).

\subsection{Scenario met gedempt getij}

Om de waterkwaliteit en ecologie te verbeteren in het Grevelingenmeer zijn er verschillende scenario's onderzocht met herintroductie van een gedempt getij middels een doorlaat in het noordelijke deel van de Brouwersdam. Het terugbrengen van het getij dient niet alleen als maatregel om de zuurstofproblematiek in het Grevelingenmeer op te lossen maar ook om de ecologie van het systeem als geheel te verbeteren.

Door Deltares zijn een paar van deze getijscenario's doorgerekend op de waterkwaliteit middels een 3D DELWAQ waterkwaliteitsmodel (Maarse et al. 2019). Om mogelijke ruimte voor schelpdierkweek te kunnen bepalen in een situatie met gedempt getij is in deze rapportage één getij scenario uitgekozen waarvoor deze berekeningen zijn uitgevoerd. Het programmateam Getij Grevelingen heeft in de zomer van 2019 de Stuurgroep geadviseerd om in de Planuitwerking te focussen op een peilbeheer met gedempt getij van $40 \mathrm{~cm}$ fluctuerend rond een middenpeil van 0,30 - NAP ("40/-30 scenario"). In het Grevelingenmeer vertaalt dit zich naar een intergetijdengebied van ca. 600 ha (Tangelder et al., 2019). De resultaten van de modellen van Deltares uit Maarse et al. (2019) zijn gebruikt als input voor deze studie.

Modelberekeningen laten zien dat met een getijslag van $40 \mathrm{~cm}$ de primaire productie zal toenemen van 289 in de huidige situatie naar $447 \mathrm{~g}-\mathrm{C} \mathrm{m}^{-2} \mathrm{j}^{-1}$ (gemodelleerd voor het jaar 2025) (Maarse et al. 2019). De toename hangt samen met een verwachte toename van stikstof waarbij ook een verhoging van de jaargemiddelde hoeveelheid fytoplankton wordt verwacht van 5.3 naar $7.6 \mathrm{mg} / \mathrm{m}^{3}$ chlorofyl. Momenteel is het Grevelingenmeer in de zomer stikstof gelimiteerd, maar er komt meer stikstof beschikbaar bij gedempt getij (Maarse et al. 2019). Fosfaatconcentraties daarentegen nemen af door de toenemende uitwisseling met de Voordelta. De nalevering van fosfaat die uit de bodem vrijkomt wordt deels afgevoerd naar de Voordelta waar de concentraties lager zijn (Maarse et al. 2019). Het zuurstofarm areaal $\left(<3 \mathrm{~g} / \mathrm{m}^{3}\right)$ is ca. 640 ha ten opzicht van 1300 hectare in de autonome ontwikkelingen zonder getij bij $10 \mathrm{~cm}$ zeespiegelstijging. Door aanwezigheid van gedempt getij kan het systeem robuuster omgaan met variatie in temperatuur (Maarse et al. 2019). Dit betekent dat variatie van het oppervlakte met langdurig lage zuurstofconcentraties minder groot zal zijn als in de huidige situatie. 


\subsection{Wat is draagkracht}

In de literatuur worden verschillende typen draagkracht onderscheiden (Inglis et al. 2000):

1. Fysieke draagkracht: Hierbij gaat het om het areaal aan geschikte ruimte die er beschikbaar is om schelpdieren te kweken. Hierbij zijn de randvoorwaarden om schelpdieren te kunnen kweken, zoals zoutgehalte, diepte, hydrodynamiek maar ook gebruik van het gebied voor andere functies (visserij, natuur, scheepvaart, enz.) van belang.

2. Productie draagkracht: Hierbij gaat het om hoeveel schelpdieren kunnen er in een systeem worden gekweekt zonder dat de kwaliteit van deze schelpdieren verminderd. De hoeveelheid voedsel dat beschikbaar is, is hiervoor een belangrijke randvoorwaarde.

3. Ecologische draagkracht: Hierbij gaat het om de hoeveelheden schelpdieren die kunnen worden gekweekt in een systeem zonder dat er negatieve effecten op het ecosysteem optreden. Er wordt dus niet alleen naar de hoeveelheid en kwaliteit van de gekweekte schelpdieren gekeken, maar ook naar de andere componenten van het ecosysteem zoals overige schelpdieren, vissen en vogels.

4. Sociale draagkracht: Hierbij gaat de impact door schelpdierkweek die door de samenleving wordt geaccepteerd.

In de praktijk zijn deze draagkracht typen niet altijd los van elkaar te zien.

De ecologische draagkracht wordt bepaald door de mogelijke effecten van schelpdierkweek op andere populaties, die onder meer via voedselcompetitie, ruimtebeslag of verstoring kunnen verlopen. Dit type draagkracht is van belang voor het beheer.

\section{Ecologische draagkracht}

De term (ecologische) draagkracht is een veelgebruikte term binnen de schelpdier aquacultuur en wordt gedefinieerd als: De maximale bestandsgrootte van schelpdieren welke geen negatieve effecten heeft op micro-algen populatie (Jansen et al. 2019). Tweekleppige schelpdieren (vb. mossel en oester) filteren fytoplankton en ander organisch materiaal uit het water. Ze worden daarom aangeduid als filterfeeders of grazers. De aanwezigheid van dit voedsel bepaald voornamelijk de draagkracht van een systeem voor schelpdieren. Zoals eerder aangegeven zijn er ook andere filtrerende bodemdieren (zakpijpen, sponzen etc), zoöplankton en planktivore vissen die leven van het fytoplankton, maar vanwege de beperkte data van deze soortengroepen wordt gefocust op schelpdieren.

Voedselbeschikbaarheid is afhankelijk van de waterbeweging (voor invoer van voedsel afkomstig van buiten het systeem en voor verdeling van het voedsel binnen het systeem) en lokale voedselproductie (nieuwe aanwas van fytoplankton door primaire productie) (Figuur 3).

In een open systeem kan een belangrijk deel van het voedsel voor de schelpdieren afkomstig zijn van de wateruitwisseling met aangrenzende gebieden. In een relatief gesloten systeem zoals het Grevelingenmeer is de schelpdierpopulatie voor hun voedsel voornamelijk afhankelijk van de lokale primaire productie. Bij een te hoge graasdruk door filterfeeders kan er sprake zijn van overbegrazing waardoor de primaire productie afneemt, en de draagkracht dus overschreden is. 


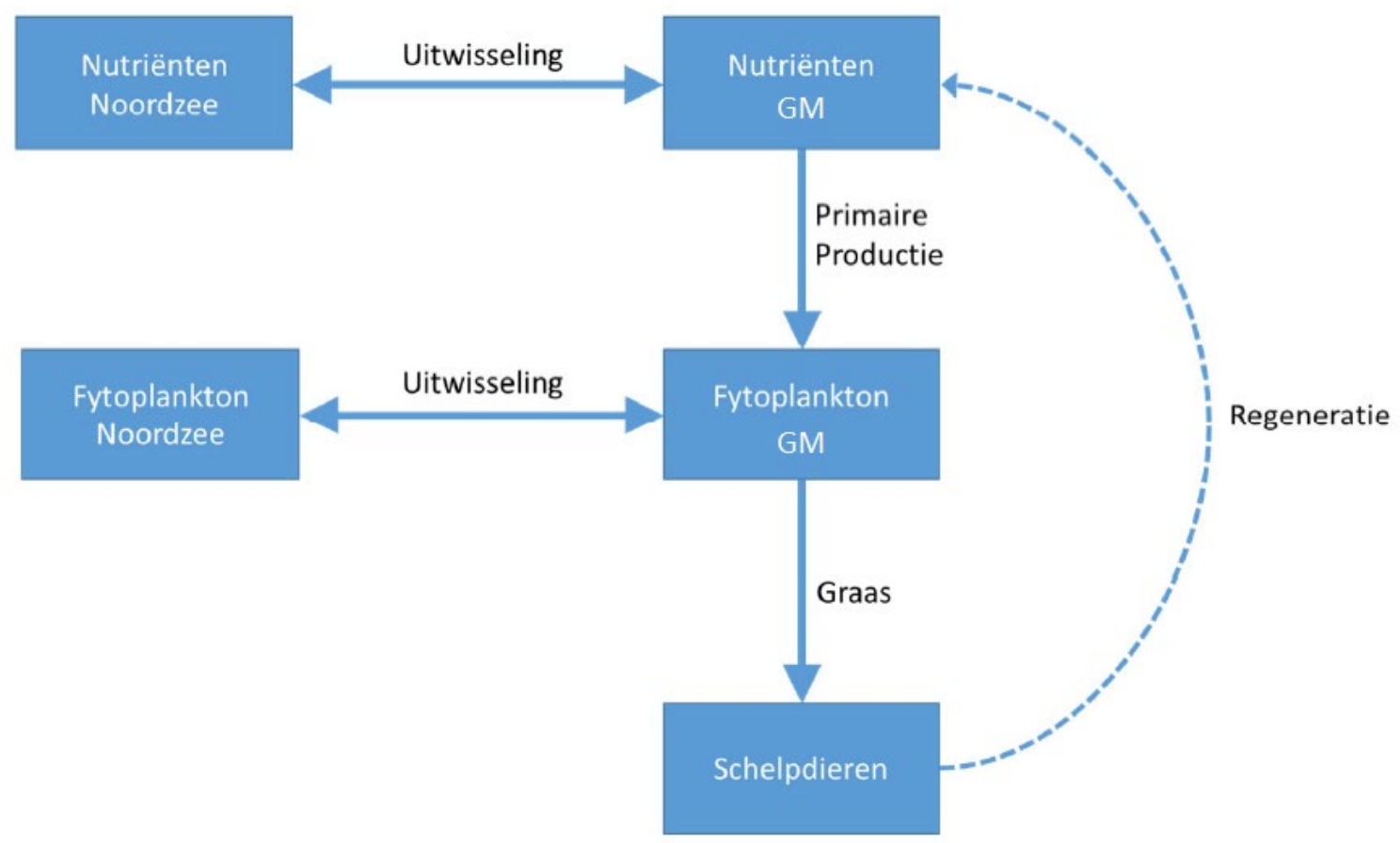

Figuur 3. Eenvoudige schematisatie van de relatie tussen nutriënten, fytoplankton en schelpdieren in het Grevelingenmeer. Nutriënten ( $N$ en $P$ ) en fytoplankton worden door getij uitgewisseld tussen

Grevelingenmeer (rechts) en Noordzee (links). In het Grevelingenmeer neemt de fytoplankton biomassa toe door primaire productie en af door begrazing. Schelpdieren leveren nutriënten versneld terug waarmee de primaire productie wordt gestimuleerd (gebaseerd op: Wijsman 2019).

De draagkracht van een gebied is het resultaat van de interactie tussen de externe aanvoer, de primaire productie en de filtratiedruk van de grazers. Daarbij geldt dat deze factoren variëren in ruimte en tijd. Verblijftijd van de watermassa in getijdenwateren is voornamelijk afhankelijk van getij. Primaire productie is afhankelijk van algenbiomassa, lichtklimaat en nutriënten. Schelpdierpopulaties en overige grazers, en dus de filtratiedruk, kunnen in omvang variëren als functie van aanwas en overleving en omgevingscondities. Voor de mosselkweek in de Oosterschelde is bijvoorbeeld bekend dat de percelen in de buurt van de Oosterscheldekering over het algemeen leiden tot relatief goede opbrengsten. Dit is waarschijnlijk het gevolg van de aanvoer van voedselrijk water vanuit de Noordzee (Smaal en Wijsman 2014). Ook kunnen watermassa's in bepaalde seizoenen ruimtelijk gescheiden zijn door gelaagdheid waardoor er onder rustige weersomstandigheden een periode van geringe menging optreedt en het voedsel de schelpdieren niet bereikt; een tijdelijke ontkoppeling kan voordelen hebben omdat het fytoplankton dan flink kan groeien totdat de watermassa onder invloed van wind weer gaat mengen en de schelpdieren weer kunnen eten (Maar et al. 2010; Herman 2012).

Doordat de bovengenoemde processen dynamisch zijn en ook ruimtelijk gedifferentieerd zal ook de draagkracht (welke biomassa aan schelpdieren kan het systeem aan) variëren in de ruimte en tijd. Modellen zijn daarom waardevol om dynamiek in de draagkracht van een systeem te kunnen kwantificeren.

\subsection{Indicatoren voor draagkracht}

Omdat gedetailleerde modellen niet altijd beschikbaar zijn wordt er doorgaans gebruik gemaakt van een aantal parameters om draagkracht van systemen met elkaar te kunnen vergelijken en om een algemene indruk te krijgen of er grote veranderingen hebben plaatsgevonden. Zo wordt er bijvoorbeeld gekeken naar veranderingen in voedsel zoals primaire productie en het chlorofyl gehalte. Een afname in primaire productie kan een indicatie zijn voor overbegrazing. Ook wordt waar mogelijk 
naar schelpdiervleesgewichten gekeken aan de veiling. Als er onvoldoende voedsel beschikbaar is zal het gemiddeld vleespercentage afnemen. Daarnaast worden in sommige gebieden met regelmaat schelpdierinventarisaties uitgevoerd waarna de graasdruk kan worden berekend. Voor sommige groepen zoals de bestanden aan sublitorale oesters en hardsubstraatorganismen dienen aannames te worden gemaakt.

Dame en Prins (1998) hebben de draagkracht uitgedrukt in een aantal eenvoudige generieke indices: de Clearance Ratio $(C R)$ en de Grazing Ratio $(G R)$. Deze ratio's worden berekend uit een aantal kenmerken van het systeem zoals de gemiddelde primaire productie $\left(P P, \mathrm{~g}-C \mathrm{~m}^{-2} \mathrm{dag}^{-1}\right)$, de gemiddelde fytoplanktonbiomassa (Fyto, $\mathrm{g}-\mathrm{C} \mathrm{\textrm {m } ^ { - 2 }}$ ), de gemiddelde verblijftijd van het water $(R T, \mathrm{~d})$ en de filtratiecapaciteit (clearance rate) door de filter feeders $\left(c r, \mathrm{~m}^{3} \mathrm{~d}^{-1}\right)$.

Uit de gemiddelde primaire productie en de gemiddelde fytoplanktonbiomassa kan de productietijd $(P T, \mathrm{~d})$ worden berekend $(P T=F y t o / P P)$. Deze parameter geeft aan hoeveel tijd het kost om de algenbiomassa in het systeem te vernieuwen. Om PT te berekenen wordt de algenconcentratie (Chla) gedeeld door de algenproductie (primaire productie). Hiertoe is de algenconcentratie (in mg Chla per $\mathrm{m}^{3}$ ) vermenigvuldigd met de gemiddelde diepte van het systeem (Tabel 5). Vervolgens zijn de primaire productie waarden (in g C per $\mathrm{m}^{2}$ per dag) omgerekend naar chlorofyl (in $\mathrm{g}$ Chla per $\mathrm{m}^{2}$ per dag) op basis van een conversie factor van $30 \mathrm{mg}$ Chla per g-C (Wetsteijn en Kromkamp 1994). Deze waarden zijn door elkaar gedeeld om tot de PT te komen.

Analoog hieraan is de filtratietijd of 'clearance time' $(C T, \mathrm{~d})$ de tijd die de filter feeders er over doen om het hele watervolume van het systeem te filtreren. Deze kan worden berekend door het volume van het systeem te delen door de filtratiesnelheid van de schelpdieren: $C T=V o l u m e / c r$. Hierbij wordt geen rekening gehouden met refiltratie waarbij schelpdieren water filtreren wat al eerder door andere schelpdieren gefiltreerd is.

De Clearance Ratio $(C R=C T / R T)$ geeft de verhouding tussen de aanvoer van voedsel uit de Noordzee en de graasdruk van de schelpdieren. $R T$ staat voor Retention Time, oftewel de gemiddelde verblijftijd van het water in het systeem. Deze waarde wordt berekend uit het getijvolume en de verversingssnelheid. Hier moet echter rekening gehouden worden met het feit dat met het getij deels hetzelfde water heen en weer wordt verplaatst. Het is dus een soort exponentiele functie (Long et al. 2019). Bij een Clearance Ratio waarden groter dan 1 is de verversing door uitwisseling groter dan de filtratie. Bij waarden kleiner dan 1 filteren de schelpdieren het water sneller dan dat het wordt ververst. Hoe lager de Clearance Ratio, hoe belangrijker de interne primaire productie van het systeem om de schelpdieren van voedsel te voorzien.

De Grazing Ratio ( $G R=C T / P T$ ) geeft verhouding tussen de interne voedsel productie (primaire productie van algen) en de graasdruk van schelpdieren. Hier wordt de clearance time (CT) gedeeld door de primaire productie (PT) om tot een schatting van de Grazing Ratio te komen.

De Clearance en Grazing Ratio staan niet los van elkaar en moeten samen geanalyseerd worden. Een lage CR door een hoge verblijftijd kan bijvoorbeeld worden gecompenseerd door een hoge lokale productie (hoge primaire productie). Vanuit de literatuur is er geen consensus over grenswaarden van CR en GR voor de benutting van de ecologische draagkracht door geëxploiteerde schelpdierpopulaties. In theorie wordt voor beide indexen een getal van 1 gebruikt, waarbij een getal lager dan 1 aangeeft dat draagkracht overschreden wordt. In bepaalde gevallen, zoals voor het ASC label voor gekweekte bestanden, wordt de grenswaarde van 3 gehanteerd voor de GR wanneer blijkt dat de CR lager is dan 1 (ASC 2012).

Daarnaast zijn er nog een aantal andere indicatoren welke een beeld geven van de draagkracht van een systeem. Zo zijn er in het verleden een aantal indicatoren voor de ontwikkeling van de draagkracht gebruikt (Smaal en Van Stralen 1990; Smaal et al. 2010; Smaal et al. 2013; Kamermans en Van Asch 2018):

- Waterkwaliteitsparameters: veranderingen in primaire productie kunnen mogelijk worden verklaard door veranderingen in waterkwaliteit (algenconcentratie, nutriënten, lichtklimaat);

- Aandeel picoplankton: bij hoge graasdruk kan het aandeel van het picoplanton (algen die te 
klein zijn om door schelpdieren te worden gegeten) aan de totale algenbiomassa toenemen;

- Veranderingen in de groei van schelpdieren als kokkels kan een indicatie zijn voor veranderingen in draagkracht. Zo wordt de groei van kokkels gemeten op een aantal vaste locaties in de Oosterschelde (Kesteloo 2006). Als alternatief kan de groei worden afgeleid uit het gemiddelde gewicht van een en tweejarige kokkels (Kamermans en Van Asch, 2018).

De uitdaging is om dergelijke analyses ook ruimtelijk uit te voeren. Primaire productie is een belangrijke, maar zeker niet de enige factor die nodig is om inzicht te verkrijgen in de draagkracht van een systeem voor schelpdieren. Graasdruk, ook door natuurlijke schelpdierpopulaties, verversingstijd en overige bovengenoemde parameters zijn minstens net zo belangrijk.

\subsection{Bestand aan schelpdieren}

\subsubsection{Kweekbestanden in het huidige Grevelingenmeer}

In het Grevelingenmeer is er bodemcultuur van platte oester (Ostrea edulis) en Japanse oester (Crassostrea gigas) op kweekpercelen (Figuur 2). Verder lopen er op kleine schaal experimenten naar de mogelijkheden voor invang van mosselzaad met mosselzaadinvanginstallaties (MZI's) en de opkweek daarvan in mosselhangculturen (MHC). De proeven vinden plaats nabij de Brouwerssluis voor de kust van Scharendijke binnen een gebied van 10 ha (Van Stralen 2018).

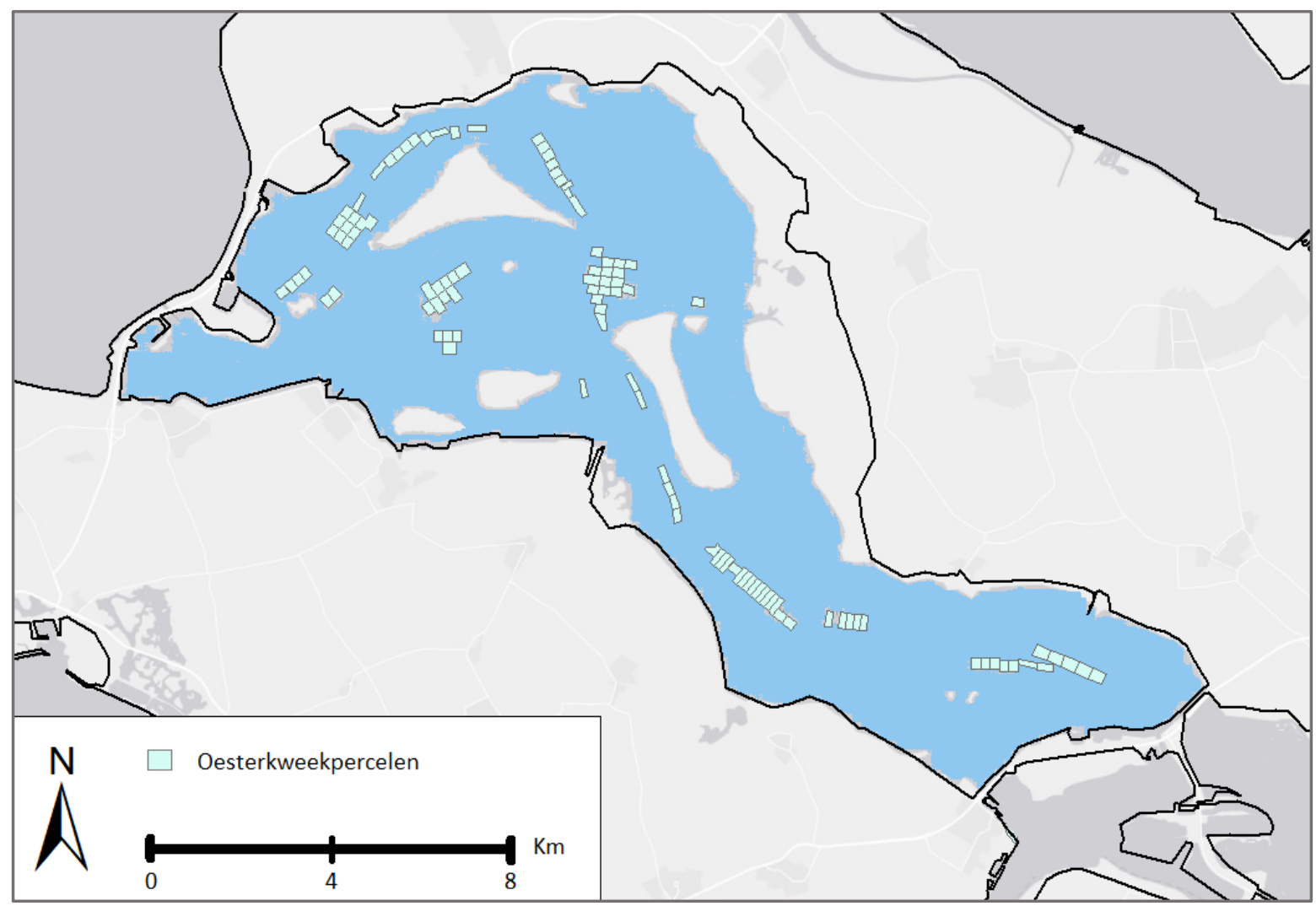

Figuur 4. Oesterpercelen Grevelingenmeer 2015.

\section{Oesterkweek}

De kweek van oesters in het Grevelingenmeer vindt plaats op afgebakende percelen. In 2015 was ca. 550 ha in het Grevelingenmeer in gebruik voor de kweek van oesters (Figuur 2), verdeeld over 16 kwekerijen (Ministerie van I\&M 2016). Elke individuele oesterkweker heeft met het Ministerie van LNV een huurovereenkomst voor het kweekrecht van oesters op deze percelen. De huurovereenkomsten met het Ministerie van LNV hebben een looptijd van drie jaar. Dit betreft alleen de oesterpercelen op de gronden van Domeinen. 
De grootte van het bestand aan gekweekte oesters in het Grevelingenmeer is bepaald aan de hand van aanlandingsdata die zijn verkregen van www.agrimatie.nl (Bronnen: Bedrijveninformatienet, Pvis, cijfers CBS 2019). De data geven de aanlandingen aan in stuks voor het Grevelingenmeer en Oosterschelde gezamenlijk. Om het bestand voor het Grevelingenmeer uit te drukken in kg versgewicht zijn de volgende aannames gedaan. 90\% van de Japanse oesters worden gekweekt in de Oosterschelde en $10 \%$ in het Grevelingenmeer. Voor de platte oesters wordt $1 \%$ gekweekt in de Oosterschelde en $99 \%$ in het Grevelingenmeer (persoonlijke mededeling Aard Cornelisse). Gebruik makend van deze aannames levert de oestercultuur in het Grevelingenmeer sinds 2001 naar schatting elk jaar ca $1 \mathrm{mln}$ platte oesters op. Echter, sinds 2013 vindt een jaarlijkse toename in productie plaats tot $7.5 \mathrm{mln}$ stuks in het seizoen 2017/2018 (Figuur 5). De platte oester heeft geleden onder de parasiet Bonamia ostrea, maar sinds 2013 treedt herstel op van het bestand in het Grevelingenmeer door de toegenomen weerstand tegen bonamia en de afnemende hoeveelheid Japanse oesters (Smaal 2017, pers. med). De Japanse oester levert in het Grevelingenmeer naar schatting op jaarbasis ca 2.7 mln stuks op (Figuur 5). Sinds 2010 neemt de aanvoer van de kweekpercelen echter af, voornamelijk door de gecombineerde impact van het herpesvirus en de Japanse oesterboorder (Productschap Vis; CBS 2019).

Om de aantallen om te zetten in gewichten is uitgegaan van 13 platte oesters per kg en 8 Japanse oesters per kg (persoonlijke mededeling Aard Cornelisse). Er wordt uitgegaan van een kweekcyclus van 3 jaar, dus de aanlandingen zijn met 3 vermenigvuldigd om de biomassa aanwezig op de percelen te schatten. Dit is een ruwe schatting omdat sterfte en groei gegevens niet bekend zijn. Daarom is de aanname dat er meer kleine oesters zijn dan grote, en dat het verschil in gewicht tussen klein en groot wordt gecompenseerd door het verschil in aantal.

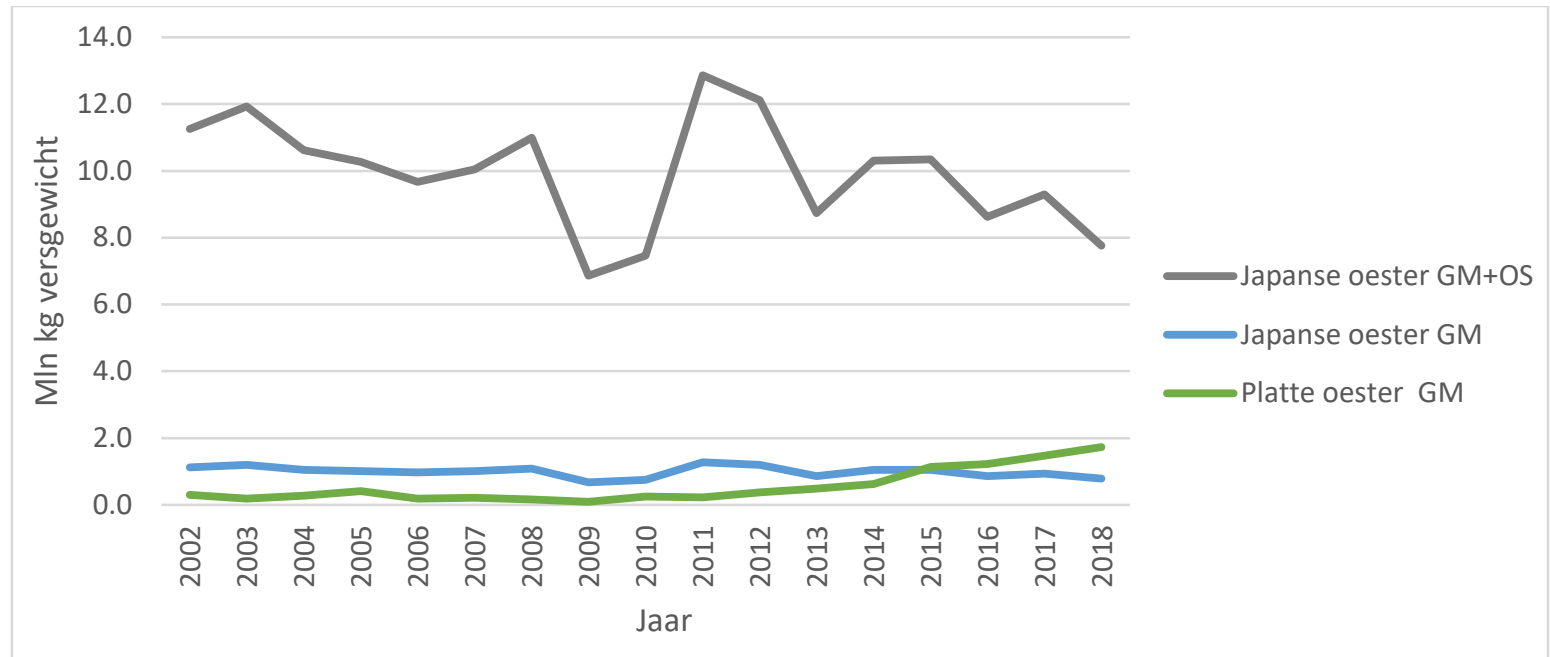

Figuur 5. Geschatte aanvoer in m/n kg versgewicht van platte (groen) en Japanse (blauw) oesters uit het Grevelingenmeer (GM) in de periode 2002-2018. De grijze lijn geeft de totale aanvoer van Japanse oesters uit het Grevelingenmeer (GR) en de Oosterschelde (OS) (gebaseerd op gegevens Bedrijveninformatienet; Mosselkantoor).

De aanvoer van de Japanse oester uit het Grevelingenmeer blijft vrij stabiel over de jaren heen en komt uit op een gemiddelde van ca. 2.7 mln stuks per jaar (Figuur 5), wat zich vertaald naar een biomassa op de percelen van ca. $1.0 \mathrm{mln} \mathrm{kg} \mathrm{versgewicht.} \mathrm{Het} \mathrm{bestand} \mathrm{van} \mathrm{de} \mathrm{platte} \mathrm{oester} \mathrm{is} \mathrm{echter}$ toegenomen in de afgelopen jaren en vertegenwoordigd in het seizoen 2017/2018 (7.5 mln stuks in de aanvoer, Figuur 5) een biomassa op de percelen van $1.7 \mathrm{mln} \mathrm{kg}$ versgewicht.

\section{Mosselkweek}

Naast de kweek van oesters in het Grevelingenmeer wordt sinds 2007 geëxperimenteerd naar de mogelijkheden voor invang van mosselzaad met MZI's nabij de Brouwersdam (Figuur 6) (Poelman en Kamermans 2010; Van Stralen 2018). In 2015 werd een eerste stap gezet naar een meer bedrijfsmatige aanpak en is het gebied toen uitgebreid van 1 ha naar 10 ha (Van Stralen 2018). Ondanks dat er succesvol MZI-zaad ingevangen kon worden, vormde de afzetmarkt nog een probleem. Daardoor is het sinds 2017 ook toegestaan om de lijnen ook als mosselhangcultuur (MHC) te gebruiken om te proberen om het geproduceerde mosselzaad op te kweken (Van Stralen 2018). 


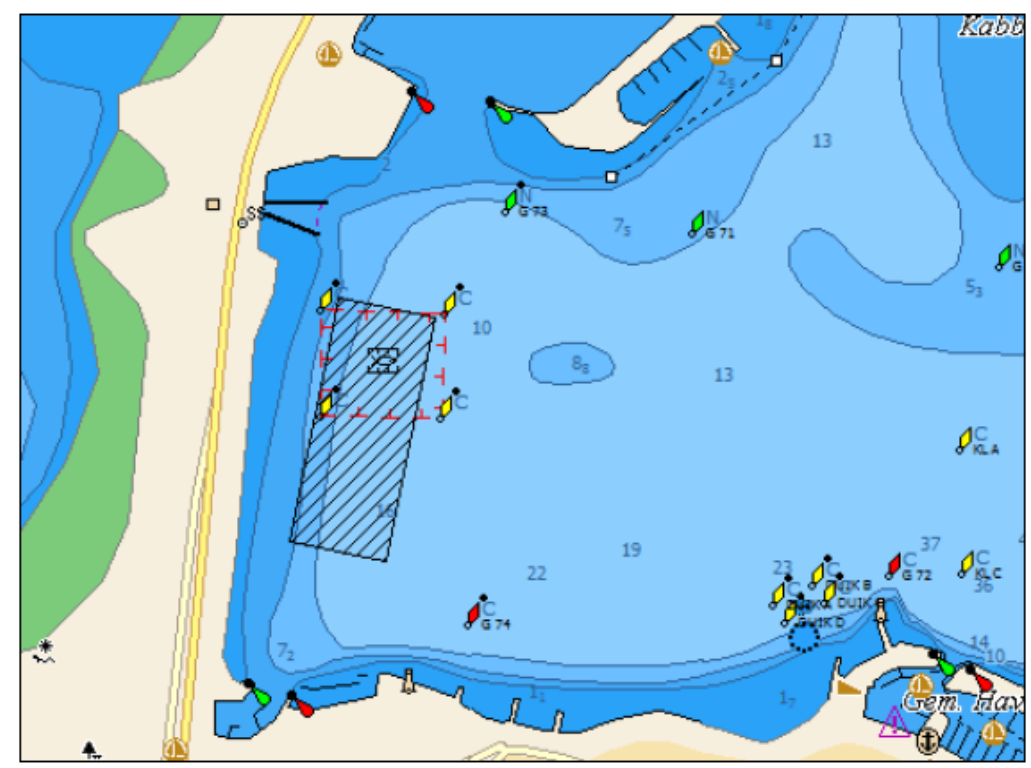

Figuur 6. MZI locaties bij de Brouwersdam, Grevelingenmeer. Het onderzoeksgebied van 10 ha is zwart gearceerd (uit: Van Stralen 2018).

In 2018 (het tweede jaar waarin met MHC werd geëxperimenteerd) is een totaal van $0.6 \mathrm{mln} \mathrm{kg}$ mosselen geoogst waarvan $0.14 \mathrm{mln} \mathrm{kg}$ afkomstig is van MZI lijnen en $0.47 \mathrm{mln} \mathrm{kg}$ van de MHC lijnen (Van Stralen 2018). De oogst van de MHC lijnen bestond uit een combinatie van mosselzaad (jaarklas 2018), halfwas en grote mosselen. Het bestand dat niet van de lijnen was gehaald werd geschat op $0.22 \mathrm{mln} \mathrm{kg}$. Dit zou betekenen dat er een totaal van $0.83 \mathrm{mln} \mathrm{kg}$ mosselen aanwezig was (Van Stralen 2018).

In een windgedreven systeem als het Grevelingenmeer is ook diepte een belangrijke randvoorwaarde voor schelpdierkweek vanwege beperkte menging en daarmee samenhangend risico op voedsel- en zuurstof tekort. Daarom kan de beschikbare fysieke ruimte onder de huidige omstandigheden worden beschouwd als een belangrijke beperkende factor voor de oesterkweek. Bij een grotere menging in het systeem door getij ontstaat er meer ruimte voor bodemcultuur, en zal moeten worden nagegaan in hoeverre andere factoren, zoals de voedselproductie, beperkend kunnen worden.

\section{Filtratiecapaciteit kweekbestand}

Voor de schelpdierkweek is de vraag met welke concurrerende populaties rekening moet worden gehouden. Dit vereist een schatting van de filtratiecapaciteit van de verschillende groepen filter feeders (Tabel 1). Om deze schatting te kunnen maken moet het versgewicht (FW) eerst omgerekend worden naar drooggewicht (DW) of as-vrij drooggewicht (AFDW). De verhouding voor het omrekenen van FW naar AFDW wordt per soort weergegeven in Tabel 1. Om te rekenen tussen DW en AFDW wordt gebruik gemaakt van de volgende conversie: AFDW/DW = $83.5 \%$ (Ricciardi en Bourget 1998).

Tabel 1. Omrekening van versgewicht (FW, inclusief schelp) naar as-vrij drooggewicht (AFDW) of drooggewicht (DW).

\begin{tabular}{ll}
\hline Soort & $\begin{array}{l}\text { Omrekening van versgewicht naar } \\
\text { (as-vrij) drooggewicht }\end{array}$ \\
\hline Japanse oester & AFDW $=F W / 100$ of $\mathrm{AFDW}=\mathrm{FW} / 50^{1,2, *}$ \\
Platte oester & $\mathrm{AFDW}=\mathrm{FW} / 100$ of $\mathrm{AFDW}=\mathrm{FW} / 50^{1,2, *}$ \\
Mossel & $\mathrm{AFDW}=\mathrm{FW} / 20^{1}$ \\
Kokkel & $\mathrm{AFDW}=\mathrm{FW} / 30^{1}$ \\
Brakwaterkokkel & $\mathrm{AFDW}=\mathrm{FW} / 30$ (hetzelfde als de kokkel) $^{1}$ \\
Filipijnse tapijtschelp & $\mathrm{AFDW}=\mathrm{FW} / 30($ hetzelfde als de kokkel) \\
Mesheft & $\mathrm{AFDW}=0.0443^{*} \mathrm{FW}+0.131^{3}$ \\
Strandgaper & $\mathrm{AFDW}=\mathrm{FW} / 15^{4}$ \\
\hline
\end{tabular}

*Er is een andere verhouding aangehouden voor natuurlijke oesters (100) dan kweekoesters (50) aangezien de kweekoesters meer vlees bevatten in verhouding met de grootte van de schelp dan natuurlijke oesters. ${ }^{1}$ Smaal et al. (2013), ${ }^{2}$ Wijsman en Smaal (2017), ${ }^{3}$ Kamermans et al. (2013), ${ }^{4}$ Ricciardi en Bourget (1998) 
Om de filtratiecapaciteit te kunnen berekenen moet het gemiddelde drooggewicht bekend zijn. Voor de gekweekte oesterbestanden zijn deze waardes berekend aan de hand van aannames gedaan in §3.3.1. Echter, voor de gekweekte mosselen was deze informatie niet beschikbaar. Daarom is gebruik gemaakt van informatie uit de Waddenzee (Capelle et al. 2016). We zijn ervan uitgegaan dat het mosselzaad uit MZI's een gemiddelde grootte heeft van $20 \mathrm{~mm}$ met bijbehorend drooggewicht (Tabel 2) (Jacobs et al. 2015; Capelle et al. 2016). Aangezien de MHC lijnen een combinatie bevatten van mosselzaad, halfwas en grote mosselen (Van Stralen 2018) wordt gerekend met een gemiddelde grootte van een halfwas mossel: $40 \mathrm{~mm}$ met bijbehorend drooggewicht (Capelle et al. 2016).

Tabel 2. Filtratiecapaciteit (clearance rate, $\mathrm{cr}$ ) van verschillende gekweekte soorten berekend aan de hand van het gemiddelde drooggewicht (DW) per individu. De formule om cleareance rate te berekenen voor de Japanse en platte oester is gebaseerd op Smaal et al. (1007) en Cranford (2001).

\begin{tabular}{|c|c|c|c|c|}
\hline Soort & $\begin{array}{l}\text { Gemiddeld } \\
\text { versgewicht } \\
\text { (g)/indiv }\end{array}$ & $\begin{array}{l}\text { Gemiddeld DW } \\
\text { (g)/indiv }\end{array}$ & $\begin{array}{l}\text { Formule clearance } \\
\text { rate }(\mathrm{cr})\end{array}$ & $\begin{array}{l}\text { Cr }\left(L^{-1}\right. \\
/ \text { indiv })\end{array}$ \\
\hline Japanse oester & 125 & 2.99 & $c r=3.92 \cdot W^{0.50}$ & 6.8 \\
\hline Platte oester & 77 & 1.84 & $c r=1.38 \cdot W^{0.83}$ & 2.3 \\
\hline Mosselkweek (MHC) & $4.5^{1}$ & $0.28^{1}$ & $c r=1.66 \cdot W^{0.57}$ & 0.7 \\
\hline Mosselzaad (MZI) & $0.3^{1}$ & $0.02^{1}$ & $c r=0.74 \cdot W^{0.67 *}$ & 0.1 \\
\hline
\end{tabular}

*Gebaseerd op Jacobs et al. (2015), ${ }^{1}$ berekening gebaseerd op informatie Waddenzee: Capelle et al. (2016)

Vervolgens zijn de filtratiesnelheden berekend voor een gemiddeld individu (Tabel 2) waarna deze zijn vermenigvuldigd met het aantal individuen in het bestand om tot de graasdruk van het totale kweekbestand schelpdieren te komen (Figuur 5). Kleinere individuen hebben echter relatief hogere filtratiesnelheden; $1 \mathrm{~kg}$ kleine mosselen zal meer filtreren dan $1 \mathrm{~kg}$ grote mosselen. Op kweekpercelen komen schelpdieren in alle grootte klassen voor. Hiervoor is niet gecorrigeerd omdat de verdeling van grootte klassen niet bekend zijn, maar ook omdat niet voor alle soorten de grootte afhankelijk coëfficiënten voor filtratiesnelheden bekend zijn.

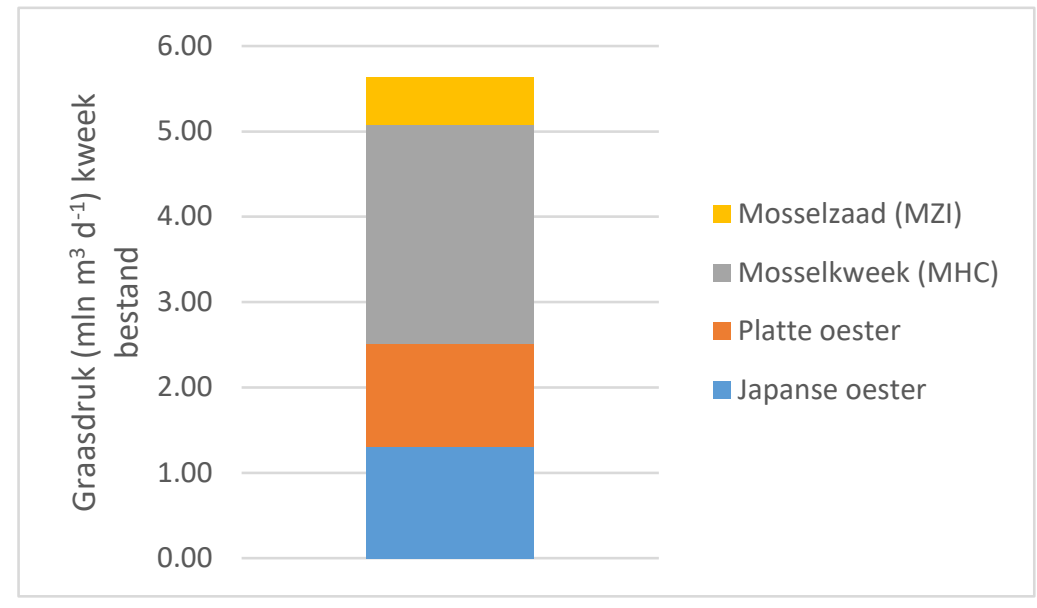

Figuur 7. Graasdruk (5.6 $\mathrm{mln} \mathrm{m}^{3} \mathrm{~d}^{-1}$ ) van het totale kweekbestand schelpdieren.

\subsubsection{Huidige naturlijke schelpdierbestanden in het Grevelingenmeer}

In 2017 is met behulp van een hydraulische happer een schelpdierinventarisatie uitgevoerd in het Grevelingenmeer binnen de wettelijke onderzoekstaken in opdracht van het ministerie van LNV, met als doel een bestandschatting van commercieel mogelijk interessante soorten (Troost et al. 2017). De bemonstering in 2017 richtte zich alleen op gebieden buiten de dichte oesterbanken. In 2018 zijn zowel de gebieden binnen de dichte oesterbanken als de gebieden daarbuiten bemonsterd.

Desondanks geeft dit nog geen volledig beeld van het gehele schelpdierbestand aangezien de monstername met hydraulische happer zich specifiek toespitst op oesters en mosselen en richt zich niet op ingegraven soorten waardoor deze mogelijk enigszins onderschat zijn (Van Zwol et al. 2019). Het was niet mogelijk een versgewicht te bepalen van de mesheften (Ensis sp.) en strandgapers (Mya arenaria) omdat de meeste schelpen van deze soorten kapot waren en/of alleen de siphonen zijn 
bemonsterd met het gebruikte monstertuig. Omdat geen gewicht gegevens van deze soorten beschikbaar zijn voor het Grevelingenmeer of de Oosterschelde, zijn gemiddelde versgewichten van de Waddenzee gebruikt (Jansen et al. 2019) om toch enigszins een inschatting te kunnen maken van het totale versgewicht in $\mathrm{kg}$ voor beide soorten.

Tabel 3. Bestandsberekening Grevelingen in 2018, aantallen weergegeven in miljoenen en gewicht in miljoenen kilo's (uit: Van Zwol et al. 2019).

\begin{tabular}{llll}
\hline Soort & Naam & Aantal in mln & Versgewicht in mln kg \\
\hline Crassostrea gigas & Japanse oester & 1213.0 & 141.7 \\
Ostrea edulis & Platte oester & 359.7 & 11.0 \\
Mytilus edulis & Mossel & 360.5 & 3.3 \\
Cerastoderma edule & Kokkel & 57.6 & 0.5 \\
Cerastoderma glaucum & Brakwaterkokkel & 11.0 & 0.1 \\
Ruditapes philippinarum & Filipijnse tapijtschelp & 197.3 & 1.0 \\
Ensis sp. & Mesheft & 63.0 & $0.9 *$ \\
Mya arenaria & Strandgaper & 5.5 & $0.03 *$ \\
\hline Totaal & & $\mathbf{2 2 6 7 . 6}$ & $\mathbf{1 5 8 . 5}$
\end{tabular}

*Voor mesheften en strandgapers kon geen versgewicht berekend worden omdat veel schelpen gebroken waren. Daarom is het gemiddelde versgewicht per individu (Jansen et al. 2019) gebruikt van de Waddenzee om alsnog een schatting te kunnen maken van het totaal versgewicht van beide soorten.

\section{Filtratiecapaciteit natuurlijke bestand}

Het gemiddelde gewicht per individu is gebruikt om de filtratiecapaciteit te berekenen. Dit gemiddelde gewicht is berekend aan de hand van Van Zwol et al. (2019), waar per soort zowel het totaal aantal individuen als het totale versgewicht in $\mathrm{kg}$ was aangegeven (Tabel 4), met uitzondering van mesheften en strandgapers, hiervoor zijn gemiddelde versgewichten van de Waddenzee gebruikt (Jansen et al. 2019). Deze versgewichten zijn omgerekend naar as-vrij drooggewichten gebruik makend van de omreken verhouding in Tabel 1 . Wel was de verhouding tussen grote en kleine mesheften bekend uit de 2018 bestandsinventarisatie in het Grevelingenmeer, welke gebruikt is om het juiste gemiddelde te berekenen (groot: $15 \mathrm{~g}$ versgewicht, klein: $4 \mathrm{~g}$ versgewicht). Voor de strandgapers was deze verhouding niet bekend en is gerekend met een gemiddelde van $5 \mathrm{~g}$ versgewicht. Het gemiddelde individuele versgewicht van oesters en mosselen is over het algemeen lager in het natuurlijke bestand in vergelijking met het kweekbestand. Dit komt omdat kweekoesters (of mosselen) meer vlees bevatten in verhouding met de grootte van de schelp in vergelijking met natuurlijke oesters of mosselen (Steenbergen et al. 2005), zie ook Tabel 1.

Tabel 4. Filtratiecapaciteit (clearance rate, cr) van verschillende soorten uit het natuurlijke bestand berekend aan de hand van het gemiddelde drooggewicht (DW) per individu.

\begin{tabular}{|c|c|c|c|c|}
\hline Soort & $\begin{array}{l}\text { Gemiddeld } \\
\text { versgewicht } \\
(\mathrm{g}) / \text { indiv }\end{array}$ & $\begin{array}{l}\text { Gemiddeld DW } \\
\text { (g)/indiv }\end{array}$ & $\begin{array}{l}\text { Formule clearance } \\
\text { rate }(\mathrm{cr})^{*}\end{array}$ & $\begin{array}{l}\text { cr }\left(L^{-1}\right. \\
\text { /indiv) }\end{array}$ \\
\hline Japanse oester ${ }^{1}$ & 117 & 1.40 & $c r=3.92 \cdot W^{0.50}$ & 4.6 \\
\hline Platte oester ${ }^{1}$ & 31 & 0.37 & $c r=1.38 \cdot W^{0.83}$ & 0.6 \\
\hline Mossel $^{1}$ & 9 & 0.54 & $c r=1.66 \cdot W^{0.57}$ & 1.2 \\
\hline Kokkel $^{1}$ & 9 & 0.36 & $c r=1.44 \cdot W^{0.69}$ & 0.7 \\
\hline Brakwaterkokkel $^{1}$ & 9 & 0.36 & $c r=1.44 \cdot W^{0.69}$ & 0.7 \\
\hline Filipijnse tapijtschelp ${ }^{2}$ & 5 & 0.20 & $5.25 \mathrm{~L} \mathrm{~h}^{-1} \mathrm{~g}$ AFDW & 0.9 \\
\hline Mesheft $^{3}$ & 14 & 0.90 & $0.4-5.3 \mathrm{~L} \mathrm{~h}^{-1}$ & 2.9 \\
\hline Strandgaper $^{4}$ & 5 & 0.40 & $c r=4.76 \cdot W^{0.71}$ & 2.5 \\
\hline
\end{tabular}

*Formule clearance rate is gebaseerd op Smaal et al. (1997) ${ }^{1}$, Debeuf $(2012)^{2}$, Witbaard en Kamermans (2010)3 $)^{3}$ Wijsman $(2011)^{3}$ en Riisgård \& Seerup (2003) 4

Ook voor het natuurlijke bestand zijn de filtratiesnelheden berekend voor een gemiddeld individu waarna deze zijn vermenigvuldigd met het aantal individuen in het bestand om tot de graasdruk van het totale natuurlijke schelpdierenbestand te komen (Figuur 6). Ook hier geldt dat kleinere individuen meer zullen filtreren dan grotere individuen. Net als voor het kweekbestand wordt hier ook niet voor gecorrigeerd in het natuurlijke bestand omdat niet voor alle soorten uit de schelpdiersurveys de 
grootte klassen gemeten zijn, maar ook omdat niet voor alle soorten de grootte afhankelijk coëfficiënten voor filtratiesnelheden bekend zijn.

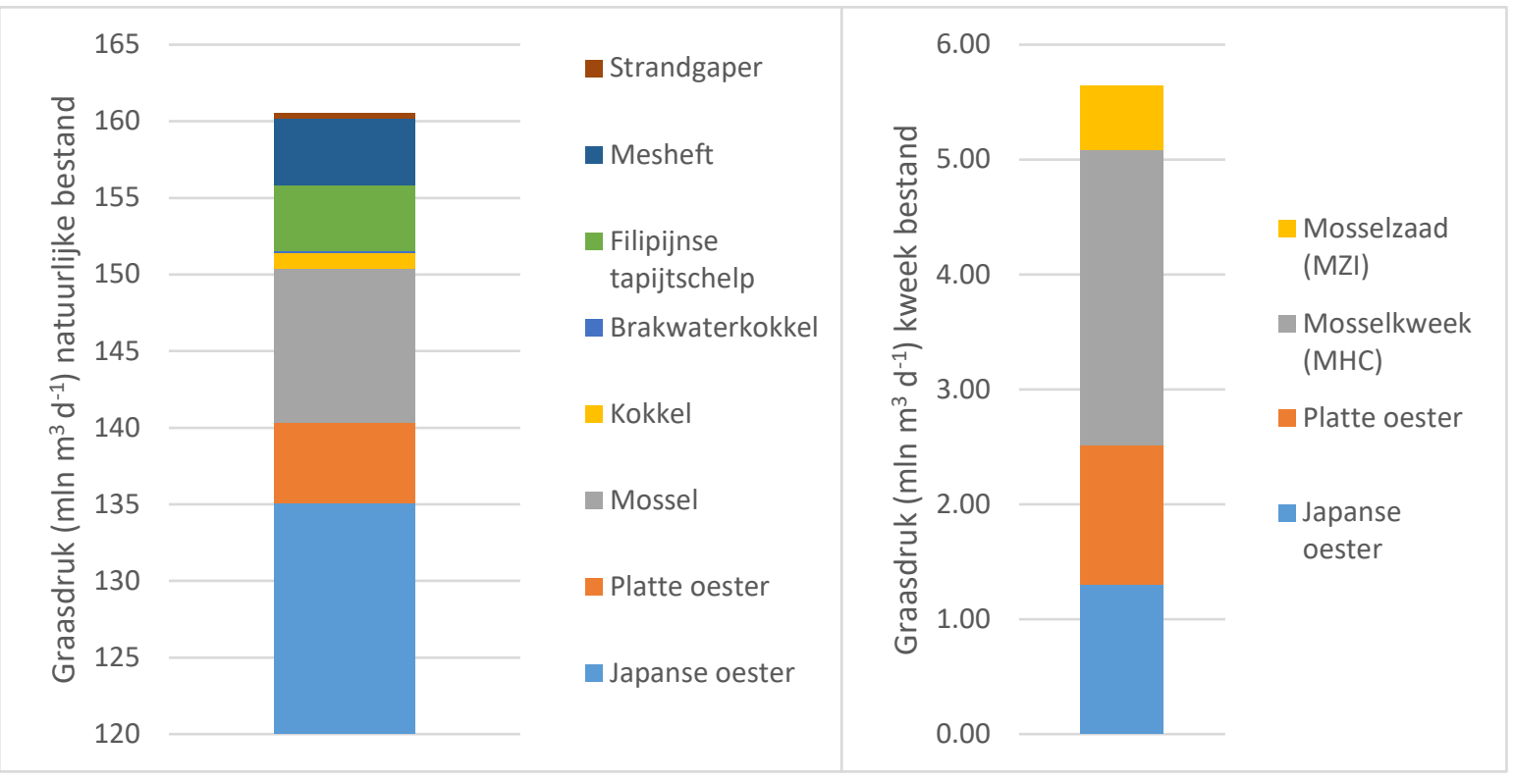

Figuur 8. Graasdruk van het natuurlijke schelpdierbestand (160.5 $\mathrm{mln} \mathrm{m}^{3} \mathrm{~d}^{-1}$; links) en het kweekbestand (5.6 $\mathrm{m} / \mathrm{n} \mathrm{m}^{3} \mathrm{~d}^{-1}$ rechts) ter vergelijking. Let op verschillen in $y$-schaal.

\subsubsection{Gevolgen van introductie gedempt getij voor schelpdierkweek}

Om de effecten van gewijzigd waterbeheer te kunnen analyseren is het van belang de karakteristieken van de huidige schelpdierkweek te beschrijven, met het oog op die parameters die door het waterbeheer gaan veranderen.

Voor schelpdiercultuur is, met name op de bodem, de toevoer van voedsel en zuurstof, en de afvoer van overtollig materiaal en uitscheidingsproducten een noodzakelijke voorwaarde. De waterbeweging is dus een belangrijke parameter. Dit geldt ook voor kweek in de waterkolom, hoewel deze culturen ook kunnen gedijen in water met minder stroming (Smaal en Wijsman 2014). Daarvoor is een zekere mate van beschutting tegen storm juist van belang, en verder is er voldoende diepgang nodig voor hangcultuur en zaadinvang (Smaal en Wijsman 2014). De voedselproductie is bepalend voor de capaciteit van het systeem voor de productie van de gekweekte soorten. Deze capaciteit wordt aangeduid met de term productie draagkracht: de maximaal haalbare productie, die duurzaam kan worden gerealiseerd, rekening houdend met de heersende (beperkende) factoren. Naast productiedraagkracht moet ook rekening worden gehouden met de ecologische draagkracht: de maximale omvang van populaties die voor de langere termijn in het systeem in stand kan worden gehouden, zonder dat er negatieve effecten op andere onderdelen van het systeem optreden.

Naast de gekweekte schelpdieren is de voorraad natuurlijke schelpdierpopulaties van belang omdat deze van dezelfde voedselbron gebruik maken en er dus competitie is om voedsel tussen de schelpdieren. Het gaat hierbij niet alleen om de biomassa maar vooral om de filtratiecapaciteit, omdat die bepalend is voor de concurrentiekracht van de soorten. Dus biomassa en filtratiecapaciteit zijn hierbij belangrijke parameters.

De introductie van gedempt getij betekent meer stroming in het Grevelingenmeer en een getijverschil van $40 \mathrm{~cm}$. Voor de schelpdierkweek biedt dit perspectieven omdat de menging in het systeem dan zal worden vergroot, hetgeen onder stagnante omstandigheden als belangrijke beperking kan worden gezien. Bovendien neemt het zuurstofarm areaal af (Maarse et al. 2019) en is uitbreiding van het leefgebied naar dieper water mogelijk (Smaal en Wijsman 2014). Er kan vanuit worden gegaan dat waterbeweging in de toekomst niet de meest beperkende factor meer zal zijn. 


\subsubsection{Draagkracht voor schelpdieren}

Omdat er geen tijdreeksen beschikbaar zijn van de ontwikkelingen in schelpdierbestanden en in voedselcondities, wordt er in de huidige studie enkel gekeken naar de Clearance Ratio en/of Grazing Ratio. De potentiele draagkracht kan worden berekend uitgaande van de verhouding tussen primaire productie tijd (PT) en filtratie tijd (CT=clearance time). De aanname (zie §3.3.1) is dat de verhouding tussen de tijd die het fytoplankton erover doet om te groeien een factor 3 korter moet zijn dan de tijd die alle schelpdieren tezamen nodig hebben om het water te filteren: CT/PT > 3. Dit levert een maximale schatting op. Deze wordt in werkelijkheid niet bereikt omdat dit complete menging van het water veronderstelt. Verder omvat deze schatting het geheel aan filtrerende schelpdieren inclusief natuurlijke bestanden. Welk deel voor kweek kan worden gebruikt hangt van de ruimtelijk inrichting af en van de doelstellingen met betrekking tot natuurbeheer. In Tabel 5 zijn de Clearance en Grazing Ratios berekend, als proxy voor de ecologische draagkracht. Welk deel van de totaal beschikbare filtratiecapaciteit wordt gebruikt voor kweek (productie draagkracht) is afhankelijk van beleidskeuzen en ontwikkelingen in de kweeksectoren.

Daarnaast lijkt gemiddelde verblijftijd een makkelijk begrip maar is nog behoorlijk complex gezien de variatie in ruimte (o.a. door stratificatie). Zo wordt er in dit rapport gebruik gemaakt van de gemiddelde verblijftijd (RT) voor het gehele systeem terwijl deze in werkelijkheid sterk kan verschillen tussen gebieden binnen het systeem. Zo is de verblijftijd nabij de Brouwersdam lager, waardoor de Clearance Ratio omhoog gaat, terwijl in het midden of oostelijk deel van het Grevelingenmeer de verblijftijd hoger is en dus de Clearance Ratio lager. De gemiddelde verblijftijd in de huidige situatie/autonome ontwikkeling is 4 tot 6 maanden (persoonlijke communicatie Arno Nolte, Deltares). Met de Flakkeese spuisluis in bedrijf is dat waarschijnlijk richting de 4 maanden. Met de introductie van $40 \mathrm{~cm}$ gedempt getij wordt de verblijftijd gereduceerd tot circa 3-4 weken (persoonlijke communicatie Arno Nolte, Deltares).

Tabel 5. Overzicht van gegevens welke gebruikt zijn voor het berekenen van de draagkracht in het Grevelingenmeer in de huidige situatie en met een scenario van $40 \mathrm{~cm}$ gedempt getij.

\begin{tabular}{|c|c|c|c|}
\hline & 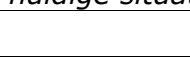 & Huidig & Toekomst \\
\hline Oppervlak & $\mathrm{km}^{2}$ & 108 & $108^{2}$ \\
\hline Gemiddelde diepte & $\mathrm{m}$ & 5.3 & $5.3^{2}$ \\
\hline Volume & $10^{6} \mathrm{~m}^{3}$ & 575 & $575^{2}$ \\
\hline Getijslag & $\mathrm{m}$ & 0 & 0.4 \\
\hline Chlorofyl & $\mathrm{mg} \mathrm{m}^{-3}$ & 5.3 & 7.6 \\
\hline Primaire productie & $g C m^{-2} j^{-1}$ & 289 & 447 \\
\hline Productie tijd (PT) & d & 1.2 & 1.1 \\
\hline Schelpdierstock & $10^{6} \mathrm{~g} \mathrm{AFDW}$ & 2078 & \\
\hline Filtratie tijd (CT) & d & 3.5 & 3.5 \\
\hline Verversingstijd (RT) ${ }^{1}$ & d & 122 & 25 \\
\hline \multicolumn{4}{|l|}{ Draagkracht indices } \\
\hline Grazing Ratio (GR) & - & 2.88 & 3.15 \\
\hline Clearance Ratio (CR) & - & 0.03 & 0.14 \\
\hline
\end{tabular}

${ }^{1}$ Communicatie Arno Nolte, Deltares

${ }^{2}$ In praktijk iets minder omdat middenpeil $10 \mathrm{~cm}$ lager komt te liggen.

De Clearance Ratio (0.03) en Grazing Ratio (2.88) (Tabel 5) in de huidige situatie geven aan dat met name de interne productie, en niet de uitwisseling met water en voedsel vanuit de Noordzee belangrijk is voor de voedselbeschikbaarheid in het Grevelingenmeer. Bovenstaande laat zien dat het niet waarschijnlijk is dat het voedsel (micro-algen) momenteel overbegraasd wordt door de aanwezige schelpdieren in de huidige situatie van het Grevelingenmeer. Wel liggen de GR waardes rond de grenswaarde voor duurzame kweek, wat aangeeft dat in de huidige situatie verdere groei van het schelpdierbestand niet mogelijk is. 


\subsubsection{Ruimte voor extra graasdruk in scenario met gedempt getij}

Door de introductie van gedempt getij zal naar verwachting de primaire productie toenemen, wat tezamen met een grotere verversing ten goede kan komen aan extra grazers zoals schelpdieren. Er zijn daarom een aantal scenario's doorberekend waarin bepaald is hoeveel het schelpdierbestand toe kan nemen in een situatie met gedempt getij wanneer er uitgegaan wordt van een gelijkblijvende Grazing Ratio ( $\mathrm{GR}=2.9)$. Voor deze berekeningen zijn de primaire productie en chlorofyl concentraties vervangen door geschatte waarden uit het model (Maarse et al. 2019) en is de verblijftijd aangepast (zie §3.3.4). Om een inschatting te maken van de hoeveelheid extra schelpdieren die het systeem aankan is gekeken naar de graasdruk $(c r)$. Figuur 9 geeft de relatie weer tussen GR en graasdruk in een situatie met gedempt tij waarbij de GR waarde daalt bij een toenemende graasdruk. Uit deze relatie blijkt dat een $\mathrm{GR}=2.88$ ( $\mathrm{GR}$ in de huidige situatie, zie tabel 5) een graasdruk van ongeveer 181 $\mathrm{mln} \mathrm{m}^{3} \mathrm{~d}^{-1}$ ondersteunt (Figuur 9).

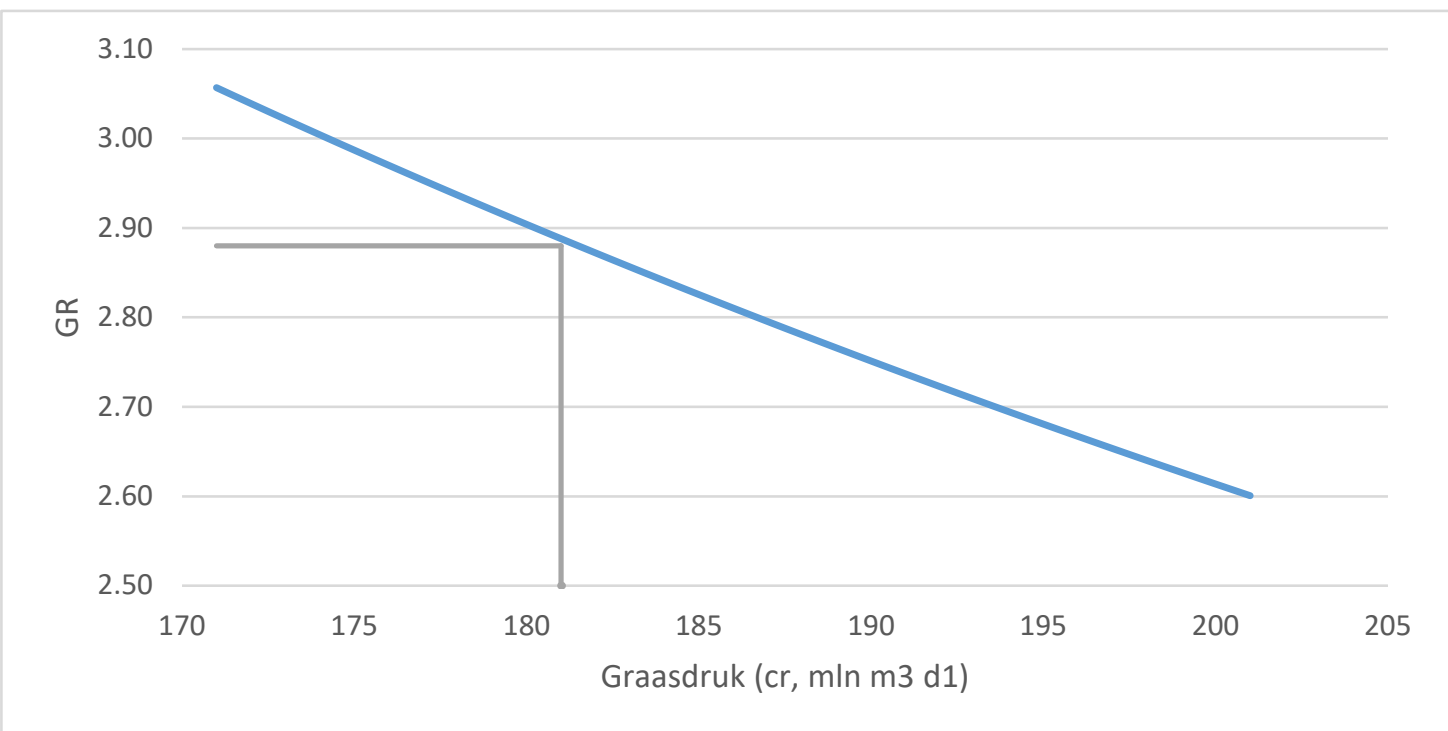

Figuur 9. Verhouding tussen toename graasdruk ( $\mathrm{cr}, \mathrm{mln} \mathrm{m}^{3} \mathrm{~d}^{-1}$ ) en Grazing Ratio (GR) (blauwe lijn) in een situatie met gedempt tij. Het snijpunt tussen de blauwe en de grijze lijn geeft de graasdruk weer die behoord tot de GR waarde van de huidige situatie.

De totale graasdruk ( $c r$ ) van het huidige schelpdierbestand is $166 \mathrm{mln} \mathrm{m}^{3}$ per dag (Tabel 6). De extra capaciteit die beschikbaar komt in een situatie met gedempt tij betreft dus $15 \mathrm{mln} \mathrm{m}^{3} \mathrm{~d}^{-1}$ voordat een Grazing Ratio van 2.88 wordt bereikt. Deze graasdruk kan door verschillende soorten schelpdieren maar ook door zoöplankton, vissen, zakpijpen, sponzen of andere filtreerders worden opgevuld. Aangezien de $\mathrm{cr}$ verschilt per soort (Tabel 4) verschillen hoeveelheden per soort. In de onderstaande tabel is voor een aantal commerciële schelpdieren bepaald hoeveel $\mathrm{mln}$ kg deze soort kan toenemen tot een graasdruk van $15 \mathrm{mln} \mathrm{m}^{3} \mathrm{~d}^{-1}$ bereikt is. De soorten moeten dus apart bekeken worden en kunnen niet bij elkaar worden opgeteld.

Tabel 6. Scenario's welke weergeven hoeveel $\mathrm{m} / \mathrm{n} \mathrm{kg}$ versgewicht van bepaalde commerciële soorten extra geproduceerd kunnen worden in een situatie met gedempt getij, t.o.v. de huidige situatie op basis van de ecologische draagkracht (GR). In de berekeningen van de oesters is gebruik gemaakt van de filtratiecapaciteit van kweekoesters (Tabel 2), en voor mosselen die van de halfwas mossel (hangcultuur, Tabel 2). De filtratiecapaciteit van de kokkel is gebaseerd op Tabel 4.

\begin{tabular}{|l|l|c|c|}
\hline & Schelpdiersoort & $\begin{array}{c}\text { Aantal individuen } \\
(\mathbf{m} \mathbf{l n})\end{array}$ & $\begin{array}{c}\text { Versgewicht in } \\
\mathbf{m} \mathbf{l n ~ k g}\end{array}$ \\
\hline Scenario 1 & Japanse oester & 95 & 12 \\
\hline Scenario 2 & Platte oester & 270 & 21 \\
\hline Scenario 3 & Mossel & 890 & 4 \\
\hline Scenario 4 & Kokkel & 880 & 8 \\
\hline
\end{tabular}




\section{$4 \quad$ Conclusie en discussie}

In deze studie is gekeken naar de verhouding tussen schelpdieren en hun voedsel in het Grevelingenmeer. De doelen hierbij waren om i) de huidige draagkracht te bepalen en ii) te berekenen hoeveel schelpdieren de extra draagkracht kunnen ondersteunen welke mogelijk beschikbaar komt in een scenario met gedempt getij als deze wordt vergeleken met de huidige graasdruk. Uit de studie blijkt dat er de introductie van gedempt getij in het Grevelingenmeer zal leiden tot meer voedsel (fytoplankton) in het systeem waardoor de graasdruk kan toenemen. Deze graasdruk kan door verschillende soorten schelpdieren maar ook door zoöplankton, vissen, zakpijpen, sponzen of andere filter feeders worden opgevuld.

\section{Ecologische draagkracht in de huidige situatie}

Om de ecologische draagkracht te kunnen bepalen zijn analyses uitgevoerd gebaseerd op Dame en Prins (1998) waarbij aan de hand van indices (Clearance Ratio, Grazing Ratio) inzicht wordt gegeven in de invloed van schelpdierbestanden op de voedselbeschikbaarheid. De Clearance Ratio (0.03) en Grazing Ratio (2.88) in de huidige situatie geven aan dat met name de interne productie, en niet de uitwisseling met water en voedsel vanuit de Noordzee belangrijk is voor de voedselbeschikbaarheid in het Grevelingenmeer. De Clearance Ratio valt onder de theoretische grenswaarde van 1. Dit geeft aan dat de filtratie van schelpdieren sneller is dan de uitwisseling met de omgeving en de schelpdieren dus meer voedsel uit het water filtreren dan wordt aangevoerd van buiten het systeem. Dit betekent dat met name de interne productie belangrijk is voor de voedselbeschikbaarheid in het Grevelingenmeer. Aangezien vooral de interne productie van voedsel bepalend is voor draagkracht moet naar de Grazing Ratio worden gekeken.

In de huidige situatie ligt de Grazing Ratio net iets onder de 3 en lijkt de voedselproductie dan ook voldoende om de filtratie van schelpdieren te compenseren. Wel liggen de GR waardes rond de grenswaarde voor duurzame kweek, wat aangeeft dat in de huidige situatie verdere groei van het schelpdierbestand niet mogelijk is. Toch zijn er wat kanttekeningen te maken bij het gebruik van dergelijke grove indices. Zo worden indices als jaarlijkse waarde per gebied berekend en de ruimtelijke en temporele variatie is gering (Jansen et al. 2019). Daarnaast wordt er gebruik gemaakt van gemiddelde verversingstijden (RT) voor het gehele systeem terwijl Jiang et al. (2019) aantoonde dat de RT in de monding van de Oosterschelde lager is dan in de Noordelijke tak en dus ook de Clearance Ratio. Ondanks dat al de Clearance Ratio's onder de 1 lagen (interne productie is ook van belang) geeft dit aan dat bij de monding de import vanuit de Noordzee belangrijker is dan in de kom van de Oosterschelde (Long et al. 2019). Dit kan ook het geval zijn voor het Grevelingenmeer. Het is dan ook waarschijnlijk dat import vanuit de Noordzee belangrijker is voor de hangcultures nabij de Brouwersdam dan de interne productie. Dit is echter moeilijk aan te tonen aangezien gerekend is met een gemiddelde verversingstijd en niet bekend is hoe deze ruimtelijk varieert.

Daarnaast is het huidige natuurlijke schelpdierbestand enkel gebaseerd op de schelpdierinventarisatie van 2018 , het eerste jaar waarin een volledige inventarisatie van het schelpdierbestand heeft plaatsgevonden in het Grevelingenmeer. Het is echter bekend dat een schelpdierbestand varieert van jaar tot jaar maar gezien de beperkte beschikbaarheid van data is het moeilijk om hierover iets te zeggen. Echter in de Oosterschelde ligt het totale schelpdierbestand gemiddeld rond de $125 \mathrm{mln} \mathrm{kg}$ waarbij de variatie per jaar kan oplopen tot $50 \mathrm{mln} \mathrm{kg} \mathrm{(40 \% )} \mathrm{(Jansen} \mathrm{et} \mathrm{al.} \mathrm{2019).} \mathrm{Daarnaast} \mathrm{wordt}$ tijdens de inventarisatie van het Grevelingenmeer niet gekeken naar schelpdierbestanden op hard substraat, zoals dijken, etc. Het huidige bestand, en daarmee de graasdruk zal daarom mogelijk onderschat zijn.

Smaal en Wijsman (2014) hebben eerder gerekend aan de draagkracht van het Grevelingenmeer om te kijken wat het maximale schelpdierbestand zou kunnen zijn in een situatie met gedempt getij. Deze resultaten verschillen echter met de resultaten uit dit rapport. Dit komt omdat toentertijd nog geen volledige inventarisatie had plaatsgevonden van het schelpdierbestand (inclusief oesterbanken) in het 
Grevelingenmeer. Het bestand is toen geschat aan de hand van de MWTL data (Wijnhoven en Hummel 2009, Wetsteijn 2011), wat resulteerde in ongeveer de helft van het huidige schelpdierbestand.

Daarnaast is gebruikt gemaakt van eerdere modellen (W\&B 2012) om tot een schatting te komen van de primaire productie in een situatie met gedempt getij. Uit het bovenstaande blijkt dat het erg belangrijk is om schelpdierbestanden goed te monitoren. De schelpdierinventarisatie in 2018 heeft pas echt een goede schatting kunnen geven van het aantal oesters. Hoe belangrijk het is om een goede schatting van het schelpdierbestand te hebben blijkt ook uit Jansen et al. (2019). Omdat het oesterbestand in het verleden veel te hoog was ingeschat leek de graasdruk al bereikt te zijn terwijl dit na een herijking van het oesterbestand niet zo bleek te zijn (Smaal et al. 2013, Jansen et al. 2019).

Ecologische draagkracht in situatie met gedempt tij Door de introductie van gedempt getij wordt verwacht dat het aantal algen (primaire productie) met een factor 1.5 zal toenemen, wat ten goede kan komen aan schelpdieren. Daarnaast zal het verdwijnen van stratificatie ook effect hebben op de verversingstijd (RT) van het Grevelingenmeer waardoor het effectief volume dat wordt uitgewisseld toeneemt. Een grotere uitwisseling van volume betekend ook een grotere aanvoer van voedsel waardoor de RT afneemt van een aantal maanden naar een aantal weken. In dit rapport is het huidige schelpdierbestand gelijk gehouden en zijn vergelijkbare berekeningen toegepast op een $40 \mathrm{~cm}$ getij scenario, dat resulteerde in een Clearance Ratio van ruim onder de 1 en een Grazing Ratio van rond de 3. De Clearance Ratio is enigszins toegenomen wat aangeeft dat in een scenario met gedempt getij de externe productie, uitwisseling van water en voedsel met de Noordzee, wat belangrijker is geworden voor de voedselbeschikbaarheid in het Grevelingenmeer. Ook nam de Grazing Ratio maar in beperkte mate toe. Omdat de Clearance Ratio nog steeds onder de 1 valt, blijft de interne productie het meest belangrijk voor de voedselbeschikbaarheid in het Grevelingenmeer, en in mindere mate de uitwisseling met water en voedsel van uit de Noordzee.

Daarnaast zijn een aantal scenario's doorberekend waarin gekeken is hoeveel schelpdieren de extra graasdruk in een situatie met gedempt getij kunnen ondersteunen als deze wordt vergeleken met de huidige Grazing Ratio ( $\mathrm{GR}=2.88$ ). Voor een aantal commerciële schelpdiersoorten is bepaald hoeveel

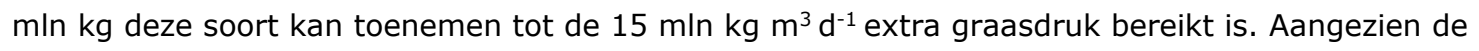
graasdruk per individu verschilt per schelpdiersoort zitten, verschilt het per soort hoeveel er nog bij zou kunnen komen: ca. $12 \mathrm{mln}$ kg Japanse oesters (12x het huidige kweekvolume), ca. $21 \mathrm{mln} \mathrm{kg}$ platte oesters (12x het huidige kweekvolume), ca. $4 \mathrm{mln} \mathrm{kg} \mathrm{mossels} \mathrm{(5x} \mathrm{huidige} \mathrm{kweekvolume)} \mathrm{of} \mathrm{ca.}$ $8 \mathrm{mln} \mathrm{kg} \mathrm{kokkels.} \mathrm{Dit} \mathrm{is} \mathrm{onder} \mathrm{de} \mathrm{aanname} \mathrm{dat} \mathrm{het} \mathrm{huidige} \mathrm{kweek-} \mathrm{en} \mathrm{natuurlijke} \mathrm{schelpdierbestand}$ gelijk blijft. Het natuurlijke bestand zal zich echter zeer waarschijnlijk ook uitbreiden aangezien er bij een grotere menging meer ruimte zal ontstaan voor natuurlijke bestanden, en andere factoren dan diepte een beperkende factor kunnen worden ( $v b$. voedsel). Aangezien verhoudingen tussen schelpdierensoorten verschuiven over de tijd is het moeilijk in te schatten hoeveel het natuurlijke bestand precies zal groeien en welke soorten het meest kunnen profiteren van toegenomen voedselbeschikbaarheid en verbeterde habitatcondities. 


\section{Aanbevelingen}

De draagkracht van een gebied is het resultaat van de interactie tussen de externe aanvoer, de primaire productie en de filtratiedruk van de grazers. Daarbij geldt dat deze factoren variëren in ruimte en tijd. Aangezien er beperkt data beschikbaar is omtrent schelpdierbestanden in het Grevelingenmeer is de evaluatie van draagkracht in dit rapport echter enkel gebaseerd op de schelpdierinventarisatie uit 2018. Om de evaluatie van draagkracht voor schelpdieren te optimaliseren worden hieronder enkele aanbevelingen gedaan over verbeteringen van metingen en analyse methodes om beter/specifieker inzicht te krijgen in de relaties tussen schelpdieren en hun voedselbronnen.

- Schelpdierpopulaties en overige grazers, en dus de filtratiedruk, kunnen in omvang variëren als functie van aanwas, overleving en omgevingscondities. De evaluatie van draagkracht in dit rapport is gebaseerd op één jaar aan data waardoor niet bekend is hoeveel het schelpdierbestand kan variëren per jaar en wat voor gevolgen dat mogelijk heeft voor de graasdruk. Draagkracht berekeningen kunnen worden geoptimaliseerd door een meerjarige reeks aan data te analyseren, mits deze beschikbaar is. Het is daarom belangrijk om het schelpdierbestand te blijven monitoren, eventuele trends te blijven volgen en specifieke aandacht te besteden aan de graasdruk van de Japanse oester, strandgaper en mesheft omdat deze in de huidige berekeningen de belangrijkste bijdrage leveren aan de totale graasdruk.

- Voor een goede schatting van de filtratiedruk is een goede schatting van het bestand aan filtrerende dieren noodzakelijk. Het is moeilijk om een goede bestandschatting te maken van mesheften en strandgapers omdat deze soorten diep in de bodem leven en de huidige survey zich specifiek toespitst op oesters en mosselen en zich niet richt op ingegraven soorten waardoor ze mogelijk onderschat worden in de huidige bestandsopnames. Het is daarom aan te bevelen extra meetpunten toe te voegen aan de survey om deze soorten beter te bemonsteren wat zal leiden tot een betere bestandschatting.

- Daarnaast zijn er geen specifieke clearance rate ( $c r$ ) gegevens (filtratiecapaciteit) beschikbaar voor mesheften en strandgapers uit Nederlandse wateren terwijl beide soorten een wezenlijke bijdrage leveren aan de totale graasdruk. De $c r$ waarde van deze twee soorten is nu gebaseerd op informatie van buiten Nederland (o.a. Riisgård \& Seerup 2003). De vraag is hoe representatief deze gegevens zijn voor mesheften en strandgapers welke in het Grevelingenmeer voorkomen. Het is daarom aan te bevelen om clearance rates te bepalen voor strandgapers en mesheften specifiek uit het Grevelingenmeer.

- Tijdens de survey worden geen oesters en mosselen op hard substraat meegenomen waardoor het schelpdierbestand mogelijk onderschat is. Wel worden soorten op hard substraat op een aantal locaties gemonitord door Stichting Zeeschelp en ook kwalitatief in kaart gebracht door vrijwilligers van Stichting Anemoon. Mogelijk kunnen deze gegevens meegenomen worden in een volgende bestandschatting om een beter beeld te krijgen van het totale schelpdierbestand.

- De indicator vleesgehalte mosselen is een goede proxy voor voedselbeschikbaarheid. Het mosselvleesgehalte is het deel van het schelpdier dat uit vlees bestaat ten opzichte van het totaal gewicht (inclusief schelp). Deze metingen worden al uitgevoerd in o.a. de Oosterschelde (Jansen et al. 2019). Directe metingen aan voedselaanbod hebben als nadeel dat er veel variatie in tijd en ruimte optreedt, terwijl metingen aan schelpdieren zelf een over de tijd geïntegreerd beeld geven van de voedselcondities (Lucas \& Beninger 1985, Filgueira et al. 2013 , 2014). Een afname van het vleesgehalte van mosselen kan wijzen op een verandering in het voedselaanbod, veroorzaakt door externe factoren (bijv. afname nutriëntenconcentraties) of door overbegrazing en dus door toegenomen schelpdierbestanden (draagkracht).

- Ook kunnen analyse technieken aangescherpt worden. Op dit moment worden de CR en GR berekend op het niveau van het gehele Grevelingenmeer. De soorten zijn echter niet evenredig verdeeld over het gebied en ook uitwisseling met water en voedsel uit de Noordzee 
(RT) is niet evenredig zoals eerder aangetoond in de Oosterschelde (Long et al. 2019). Met de introductie van gedempt getij zal het verdwijnen van de stratificatie ook effect hebben op de verversingstijd van het Grevelingenmeer waardoor het effectief volume dat wordt uitgewisseld toeneemt. Een grotere uitwisseling van volume betekend ook een grotere aanvoer van voedsel. Hoe dit zich op een ruimtelijk schaal verspreidt binnen het Grevelingenmeer is nog onduidelijk maar dit zou aan de hand van modellen inzichtelijk gemaakt kunnen worden. 


\section{$6 \quad$ Kwaliteitsborging}

Wageningen Marine Research beschikt over een ISO 9001:2015 gecertificeerd kwaliteitsmanagementsysteem. Dit certificaat is geldig tot 15 december 2021. De organisatie is gecertificeerd sinds 27 februari 2001. De certificering is uitgevoerd door DNV GL.

Het chemisch laboratorium te IJmuiden beschikt over een EN-ISO/IEC 17025:2017 accreditatie voor testlaboratoria met nummer L097. Deze accreditatie is geldig tot 1 april 2021 en is voor het eerst verleend op 27 maart 1997; deze accreditatie is verleend door de Raad voor Accreditatie. Het chemisch laboratorium heeft hierdoor aangetoond in staat te zijn op technisch bekwame wijze valide resultaten te leveren en te werken volgens de ISO17025 norm. De scope (L097) met de geaccrediteerde analysemethoden is te vinden op de website van de Raad voor Accreditatie (www.rva.nl).

Op grond van deze accreditatie is het kwaliteitskenmerk $\mathrm{Q}$ toegekend aan de resultaten van die componenten die op de scope staan vermeld, mits aan alle kwaliteitseisen is voldaan. Het kwaliteitskenmerk Q staat vermeld in de tabellen met de onderzoeksresultaten. Indien het kwaliteitskenmerk $Q$ niet staat vermeld is de reden hiervan vermeld.

De kwaliteit van de analysemethoden wordt op verschillende manieren gewaarborgd. De juistheid van de analysemethoden wordt regelmatig getoetst door deelname aan ringonderzoeken waaronder die georganiseerd door QUASIMEME. Indien geen ringonderzoek voorhanden is, wordt een tweede lijnscontrole uitgevoerd. Tevens wordt bij iedere meetserie een eerstelijnscontrole uitgevoerd. Naast de lijnscontroles wordende volgende algemene kwaliteitscontroles uitgevoerd:

- Blanco onderzoek.

- Terugvinding (recovery).

- $\quad$ Interne standaard voor borging opwerkmethode.

- Injectie standard.

- Gevoeligheid.

Bovenstaande controles staan beschreven in Wageningen Marine Research werkvoorschrift ISW 2.10.2.105.

Indien gewenst kunnen gegevens met betrekking tot de prestatiekenmerken van de analysemethoden bij het chemisch laboratorium worden opgevraagd.

Indien sprake is van onbeheerste kwaliteit worden passende maatregelen genomen. 


\section{Literatuur}

ASC (2012) ASC bivalve standard. Aquaculture Stewardship Council, Utrecht.

Arts, F.A., Lilipaly, S.J., Hoekstein, M.S.J., Van Straalen, K.D., Sluijter, M. \& Wolf, P.A. (2019) Watervogels en zeezoogdieren in de Zoute Delta 2017/2018. Rijkswaterstaat, Centrale informatievoorziening Rapport BM 19.08. Deltamilieu Projecten Rapportnr. 2019-04. Deltamilieu Projecten, Vlissingen.

Bannink, B. A., J. H. M. Van der Meulen en P. H. Nienhuis (1984) Lake Grevelingen: from an estuary to a saline lake. An introduction. Netherlands Journal of Sea Research 18: 179-190.

Bouma, S., Lengkeek, W., Boudewijn, T.J., Turlings, L.G., Abma, R. \& Nieuwkamer, R.L.J. (2008) Notitie knelpunten autonome ontwikkeling, onderdeel verkenning "Grevelingen water en getij". Ministerie van Verkeer en Waterstaat: 47.

Brasseur, S.M.J.M. \& Reijnders, P.J.H. (1994) Invloeden van diverse verstoringsbronnen op het gedrag en habitatgebruik van gewone zeehonden: consequenties voor de inrichting van het gebied. IBN-rapport. $62 \mathrm{p}$.

Capelle, J.J., Wijsman, J.W.M., Van Stralen, M.R., Herman, P.M.J. \& Smaal, A.C. (2016) Effect of Seeding density on biomassa production in mussel bottom culture. Journal of Sea Research 110: 8-15.

Cranford, P., Ward, J.E. \& Shumway, S. (2011) Bivalve filter feeding: Variability and limits of the aquaculture biofilter. In: Shellfish Aquaculture and the Environment. Ed Shumway. Wiley \& Blackwell, 81-124.

Dame, R.F. \& Prins, T.C. (1998) Bivalve carrying capacity in coastal ecosystems. Aquatic Ecology 31: 409-421.

Davis, H.C. \& Ansell, A.D. (1962) Survival and growth of larvae of the European oyster (Ostrea edulis) at lowered salinities. Biological Bulletin 122: 33-39.

Debeuf, B. (2012) Filtration and assimilation efficiency of Ruditapes philippinarum; why do they not keep growing? Agricultural Sciences <dumas-00766290>.

Dienst Landelijk gebied 2014a. Natuureffectstudie bij de Rijksstructuurvisie Grevelingen en VolkerakZoommeer Deel 1: beschrijving effecten. Utrecht, $116 \mathrm{p}$.

Dienst Landelijk gebied 2014b. Natuureffectstudie bij de Rijksstructuurvisie Grevelingen en VolkerakZoommeer Deel 2: toetsing aan de natuurwetgeving en landelijke doelen. Utrecht, $48 \mathrm{p}$.

deZwaan, A. \& Eertman, R.H.M. (1996) Anoxic or aerial survival of bivalves and other euryoxic invertebrates as a useful response to environmental stress - A comprehensive review. Comparative Biochemistry and Physiology C - Pharmacology Toxicology \& Endocrinology 113: 299-312.

Filgueira, R., Comeau, L.A., Landry, T., Grant, J., Guyondet, T. \& Mallet, A. (2013) Bivalve condition index as an indicator of aquaculture intensity: A meta-analysis. Ecological Indicators 25: 215229.

Filgueira, R., Guyondet, T., Comeau, L.A. \& Grant, J. (2014) Physiological indices as indicators of ecosystem status in shellfish aquaculture sites. Ecological Indicators 39: 134-143.

Herman, P.M.J. (2012) The effect of partial spatial isolation between mussels and their algal food on carrying capacity. NIOZ-Yerseke report. Hoofdstuk 2.

Inglis, G.J., Hayden, B.J. en Ross, A.H. (2000) An overview of factors affecting the carrying capacity of coastal embayments for mussel culture. NIWA, rapport nummer: client report: CHC00/69.

Jacobs, P., Troost, K., Riegman, R., Van der Meer, J. (2015) Length- and weight-dependent clearance rates of juvenile mussels (Mytilus edulis) on various planktonic prey items. Helgoland Marine Research 69: 101-112.

Jansen, H., Kamermans, P., Glorius, S. \& Van Asch, M. (2019) Draagkracht van de Oosterschelde en westelijke Waddenzee voor schelpdieren - Evaluatie van veranderingen in de voedselconditie en schelpdierbestanden in relatie tot de mosselkweek in de periode 1990-2016. Wageningen Marine Research Wageningen UR (University \& Research Centre), Wageningen Marine Research rapport C096/19.

Kamermans, P. (2017) Passende beoordeling ten behoeve van experimentele oesterkweek op Windgat percelen in de Kom van de Oosterschelde. Wageningen University \& Research, rapport c031/17. 
Kamermans, P. \& Van Asch, M. (2018) Monitoring draagkracht voor schelpdieren in relatie tot opschaling MZIs in de Waddenzee en de Oosterschelde. Wageningen Marine Research, Rapport nummer: C043/18.

Kamermans, P., Jak, R., Jacobs, P. Riegman, R. (2013) Groei en begrazing van mosselzaad, primaire productie en picoplankton in de Waddenzee, Oosterschelde en Voordelta. Wageningen Marine Research Rapport C187/13.

Kesteloo, J.J. (2006) Kokkelgroei en overleving in de zomerperiode in de Westerschelde. Wageningen IMARES, Rapport nummer: C055/06.

Kingston, P. (1974) Some observations on the effects of temperature and salinity upon the growth of Cardium edule and Cardium glaucum larvae in the laboratory. Journal of the Marine Biological Association of the United Kingdom 54: 309-317.

Jiang, L., Gerkema, T., Wijsman, J.W.M. \& Soetaert, K. (2019) Comparing physical and biological impacts on seston renewal in a tidal bay with extensive shellfish culture. Journal of Marine Systems 194: 102-110.

Lucas, A., Beninger, P.G. (1985) The use of physiological condition indices in marine bivalve aquaculture. Aquaculture 44: 187-200.

Maar, M., Timmermann, K. Petersen, J.K., Gustafsson, K.E. en Storm, L.M. (2010) A model study of the regulation of the blue mussels by nutrient loadings and water column stability in a shallow estuary, the Limfjorden. J Sea Research 64: 322-333.

Maarse, M., Nolte, A., Kleissen, F., Becker, B. (2019) Optimalisatie van peilbeheer Getij Grevelingen door aansturing van het doorlaatmiddel in de Brouwersdam. Deltares rapport. 11203818-001ZKS-0003. P 29.

Ministerie van I\&M (2015) Natura 2000 Deltawateren, Oosterschelde beheerplan 2015-2021. 95 p.

Ministerie van I\&M (2016) Natura 2000 Deltawateren, Grevelingen beheerplan 2016-2022. $91 \mathrm{p}$.

Ministerie van LNV (2006) Natura 2000 doelendocument, versie 1.1. 228 p.

Ministerie van LNV (2018) Ontwerp-wijzigingsbesluit Habitatrichtlijngebieden vanwege aanwezige waarden. Directie Natuur \& Biodiversiteit, DN\&B/2018-000.

Poelman, M. \& Kamermans, P. (2010) Inventarisatie MZI oogst 2009. IMARES Wageningen UR, rapport C033/10. 33 p.

Ricciardi, A. \& Bourget, E. (1998) Weight-to-weight conversion factors for marine benthic macroinvertebrates. Marine ecology progress series 163: 245-251.

Riisgård, H.U. \& Seerup, D.F. (2003) Filtration rates in the soft clam Mya arenaria: effects of temperature and body size. Sarsia 88: 415-428.

Schuiling, E. \& Smaal, A.C. (1998) Het zoet in de pap. Een literatuurstudie naar de effecten van verhoogde zoetwatertoevoer op commercieel belangrijke soorten in de Oosterschelde. RIVODLO, Rapport nummer: C041/98, 48 p.

Smaal, A. (2017) Draagkracht voor schelpdieren: definities, indices en case studies. Wageningen Marine Research rapport C023/17. 27 p.

Smaal, A.C. \& Van Stralen, M.R. (1990) Average annual growth and condition of mussels as a function of food source. Hydrobiologia 195: 179-188.

Smaal, A.C. \& Prins, T.C. (1993) The uptake of organic matter and the release of inorganic nutrients by bivalve suspension feeder beds, pages 271-298. In: R.F. Dame, ed. Bivalve filter feeders in estuarine and coastal ecosystem processes. NATO ASI Series G. Berlin, Springer Verlag.

Smaal, A.C. \& Wijsman, J.W.M. (2014) Kansen voor schelpdiercultuur in Grevelingen en VolkerakZoommeer bij ander waterbeheer. IMARES Wageningen UR, rapport C045/14. 32 p.

Smaal, A.C. \& van Duren, L.A. (2019) Bivalve Aquaculture Carrying Capacity: Concepts and assessment tools. In: Smaal, A., Ferreira, J., Grant, J., Petersen, J., Strand, Ø. (eds) Goods and services of marine bivalves. Springer, Cham.

Smaal, A.C., Vonck, A.P.M.A. \& Bakker, M. (1997) Seasonal variation in physiological energetics of Mytilus edulis and Cerastoderma edule of different size classes. Journal of the Marine Biological Association of the United Kingdom 77: 817-838.

Smaal, A.C., J.W.M. Wijsman \& Van Stralen, M. (2010) Mussel culture and subtidal mussel stock management in the western Wadden Sea: are exploitation and conservation compatible? Wadden Sea Ecosystems 26: 95-100. 
Smaal, A.C., T. Schellekens, Van Stralen, M.R. \& Kromkamp, J.C. (2013) Decrease of the carrying capacity of the Oosterschelde estuary (SW Delta, NL) for bivalve filter feeders due to overgrazing? Aquaculture 404-405: 28-34.

Smaal, A., Kamermans, P., Kleissen, F., Van Duren, L. en Van der Have, T. (2017) Platte oesters in offshorewindparken (POP). Wageningen Marine Research, Rapport C035/17.

Steenbergen, J., Breen, V. \& Jol, J. (2005) LNV bestek mosselen en eidereenden Deelproject 3: Een vergelijking van de kwaliteit van mosselen op percelen en in het wild. RIVO, rapport C086/05.

Tangelder, M., Ysebaert, T., Wijsman, J., Janssen, J., Mulder, I., Nolte, A., Stolte, W., Van Rooijen, N. \& Van den Bogaart, L. (2019) Ecologisch onderzoek Getij Grevelingen. Onderzoek naar de historische ontwikkeling van het watersysteem en inschatting van de autonome ontwikkeling vergeleken met getijscenario's en effecten op Natura 2000-soorten en habitats bij gedempt getij. Wageningen Marine Research, rapport C089/19.

Troost, T.A., Wijsman, J.W.M., Saraiva, S. en Freitas, V. (2010) Modelling shellfish growth with dynamic energy budget models: an application for cockles and mussels in the Oosterschelde (southwest Netherlands). Phil. Trans. R. Soc. B 365: 3567-3577.

Troost, K., Brummelhuis, E.B.M., Van Asch, M. \& Van Zwol, J. (2017a) Schelpdierbestanden in het Veerse meer en Grevelingenmeer in 2017. CVO rapport: 17.015.

Van Broekhoven, B.J.L. (2010) Alternatieve gronden. Verkenning naar potentiële vrije locaties voor de bodemkweek van mosselen in de Oosterschelde. RWS Directie Zeeland, $35 \mathrm{p}$.

Van Stralen, M. (2018) Invang van mosselzaad met MZI en de opkweek daarvan in MHC in de Grevelingen. Resultaten 2018. Marinx, rapport 2019-186. 11 p.

Van Zwol, J., Troost, K., Brummelhuis, E., Van den Ende, D., Van der Pool, J. \& Van Asch, M. (2019) Schelpdieren in het Veerse Meer en Grevelingenmeer in 2018. Stichting Wageningen Research Centrum voor Visserijonderzoek, CVO rapport 19.012.

VBC (Visstandbeheercommissie) Grevelingenmeer (2010) Visplan Grevelingenmeer, Rapport, 108 pagina's.

Visser, J. (1995) Het Grevelingenmeer, natuurlijk ingericht. Achtergronden van 25 jaar inrichting en beheer. Min. Verkeer en Waterstaat, Dir IJsselmeergebied, Rapport nummer: 378, 85 p.

W\&B (2012) MIRT Verkenning Grevelingen. Milieueffectrapport. Witteveen \& Bos, Rapport, 55 p.

Walles, B. \& Ysebaert, T. (2019) Potentiële verstoringsbronnen voor vogels in de Westerschelde: een interactieve kaart. Wageningen University \& Research rapport C047/19.

Wetsteijn, L.P.M.J. (2011) Grevelingenmeer: meer kwetsbaar. Een beschrijving van de ecologische ontwikkelingen voor de periode 1999 t/m 2008-2010 in vergelijking met de periode $1990 \mathrm{t} / \mathrm{m}$ 1998. Rijkswaterstaat Waterdienst, Lelystad. 163 p.

Wetsteijn, L.P.M.J. \& Kromkamp, J. (1994) Turbidity, nutrients and phytoplankton primary production in the Oosterschelde (The Netherlands) before, during and after a large-scale coastal engineering project (1980-1990). Hydrobiologia 282/283: 61-78.

Wijnhoven, S. \& Hummel, H. (2009) Historische analyse exoten in de Zeeuwse delta. De opkomst, verspreiding, ontwikkeling en impact van exoten onder de macrofauna van het zachte substraat in de Zeeuwse brakken en zoute wateren. NIOO-CEME, Yerseke, The Netherlands. Monitor Taskforce Publication Series 2009-11, 192 p.

Wijsman, J.W.M. (2002) Stratificatie en zuurstofdeficiëntie in het Grevelingenmeer. RIKZ Middelburg, Rapport nummer: RIKZ/ZB/2002.819X, 64 p.

Wijsman, J.W.M. (2011) Dynamic Energy Budget (DEB) parameters for Ensis directus. IMARES Wageningen UR, rapport C116/11.

Wijsman, J.W.M. (2019) Meten van primaire productie in de Oosterschelde, Grevelingenmeer en het Veerse Meer. Wageningen Marine Research rapport C022/19.

Wijsman, J.W.M. \& Smaal, A.C. (2011) Growth of cockles (Cerastoderma edule) in the Oosterschelde described by a Dynamic Energy Budget Model. Journal of Sea Research 66: 372-380.

Wijsman, J.W.M. \& F.M. Kleissen (2012) Potenties van een zout Volkerak-Zoommeer voor mosselen oestercultuur. IMARES, Rapport nummer: C180/11.

Wijsman, J.W.M. \& Smaal, A.C. (2017) The use of shellfish for pre-filtration of marine intake water in a reverse electro dialysis energy plant - inventory of potential shellfish species and design of conceptual filtration systems. Wageningen University \& Research Report C078/17.

Witbaard, R. \& Kamermans, P. (2010) De bruikbaarheid van de klepstandmonitor op Ensis directus ten behoeve van de monitoring van aan zandwinning gerelateerde effecten. NIOZ rapport 200910. 


\section{Verantwoording}

Rapport C006/21

Projectnummer: 4313200012

Dit rapport is met grote zorgvuldigheid tot stand gekomen. De wetenschappelijke kwaliteit is intern getoetst door een collega-onderzoeker en het verantwoordelijk lid van het managementteam van Wageningen Marine Research

Akkoord:

Datum:

Akkoord:

Handtekening:

Datum:
Henrice Jansen

Onderzoeker schelpdier ecologie

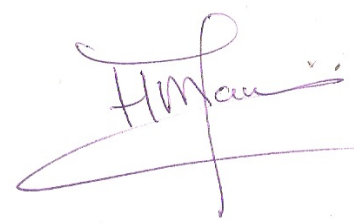

28 januari 2021

Jakob Asjes

MT-lid integratie

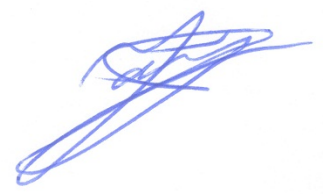

28 januari 2021 
Wageningen Marine Research

T: +31(0)317480900

E: marine-research@wur.nl

www.wur.nl/marine-research

Bezoekers adres:

- Ankerpark 271781 AG Den Helder

- Korringaweg 7, 4401 NT Yerseke

- Haringkade 1, 1976 CP IJmuiden
Wageningen Marine Research levert met kennis, onafhankelijk wetenschappelijk onderzoek en advies een wezenlijke bijdrage aan een duurzamer, zorgvuldiger beheer, gebruik en bescherming van de natuurlijke rijkdommen in zee-, kust- en zoetwatergebieden.
Wageningen Marine Research is onderdeel van Wageningen University \& Research. Wageningen University \& Research is het samenwerkingsverband tussen Wageningen University en Stichting Wageningen Research en heeft als missie: 'To explore the potential of nature to improve the quality of life' 